Atmos. Chem. Phys., 12, 4539-4554, 2012

www.atmos-chem-phys.net/12/4539/2012/

doi:10.5194/acp-12-4539-2012

(C) Author(s) 2012. CC Attribution 3.0 License.

\title{
Nitrogen deposition to the United States: distribution, sources, and processes
}

\author{
L. Zhang ${ }^{1,2}$, D. J. Jacob ${ }^{1,2}$, E. M. Knipping ${ }^{3}$, N. Kumar ${ }^{4}$, J. W. Munger ${ }^{1,2}$, C. C. Carouge ${ }^{2}$, A. van Donkelaar ${ }^{5}$, \\ Y. X. Wang ${ }^{6}$, and D. Chen ${ }^{7}$ \\ ${ }^{1}$ Department of Earth and Planetary Sciences, Harvard University, Cambridge, MA, USA \\ ${ }^{2}$ School of Engineering and Applied Sciences, Harvard University, Cambridge, MA, USA \\ ${ }^{3}$ Electric Power Research Institute, Washington, DC, USA \\ ${ }^{4}$ Electric Power Research Institute, Palo Alto, CA, USA \\ ${ }^{5}$ Department of Physics and Atmospheric Science, Dalhousie University, Halifax, Canada \\ ${ }^{6}$ Ministry of Education Key Laboratory for Earth System Modeling, Center for Earth System Science, Institute for Global \\ Change Studies, Tsinghua University, Beijing, China \\ ${ }^{7}$ Department of Atmospheric and Oceanic Sciences, University of California, Los Angeles, CA, USA
}

Correspondence to: L. Zhang (linzhang@fas.harvard.edu)

Received: 29 November 2011 - Published in Atmos. Chem. Phys. Discuss.: 3 January 2012

Revised: 24 April 2012 - Accepted: 27 April 2012 - Published: 24 May 2012

\begin{abstract}
We simulate nitrogen deposition over the US in 2006-2008 by using the GEOS-Chem global chemical transport model at $1 / 2^{\circ} \times 2 / 3^{\circ}$ horizontal resolution over North America and adjacent oceans. US emissions of $\mathrm{NO}_{\mathrm{x}}$ and $\mathrm{NH}_{3}$ in the model are 6.7 and $2.9 \mathrm{Tg} \mathrm{N} \mathrm{a}^{-1}$ respectively, including a $20 \%$ natural contribution for each. Ammonia emissions are a factor of 3 lower in winter than summer, providing a good match to US network observations of $\mathrm{NH}_{\mathrm{x}}\left(\equiv \mathrm{NH}_{3}\right.$ gas + ammonium aerosol) and ammonium wet deposition fluxes. Model comparisons to observed deposition fluxes and surface air concentrations of oxidized nitrogen species $\left(\mathrm{NO}_{\mathrm{y}}\right)$ show overall good agreement but excessive wintertime $\mathrm{HNO}_{3}$ production over the US Midwest and Northeast. This suggests a model overestimate $\mathrm{N}_{2} \mathrm{O}_{5}$ hydrolysis in aerosols, and a possible factor is inhibition by aerosol nitrate. Model results indicate a total nitrogen deposition flux of $6.5 \mathrm{Tg} \mathrm{N} \mathrm{a}^{-1}$ over the contiguous US, including 4.2 as $\mathrm{NO}_{\mathrm{y}}$ and 2.3 as $\mathrm{NH}_{\mathrm{x}}$. Domestic anthropogenic, foreign anthropogenic, and natural sources contribute respectively $78 \%$, $6 \%$, and $16 \%$ of total nitrogen deposition over the contiguous US in the model. The domestic anthropogenic contribution generally exceeds $70 \%$ in the east and in populated areas of the west, and is typically $50-70 \%$ in remote areas of the west. Total nitrogen deposition in the model exceeds $10 \mathrm{~kg} \mathrm{Nha}^{-1} \mathrm{a}^{-1}$ over $35 \%$ of the contiguous US.
\end{abstract}

\section{Introduction}

Atmospheric input of reactive nitrogen (often called "fixed nitrogen") to ecosystems has increased by more than a factor of 3 globally due to human activity, significantly perturbing the global nitrogen cycle (Vitousek et al., 1997; Galloway et al., 2004). Adverse effects may include soil acidification (Bowman et al., 2008), eutrophication (Bouwman et al. 2002), and a reduction in plant biodiversity (Stevens et al., 2004). Increased nitrogen deposition may enhance $\mathrm{CO}_{2}$ uptake by the land and ocean, though the climate benefit would be offset by associated $\mathrm{N}_{2} \mathrm{O}$ emission (Reay et al., 2008). The US Environmental Protection Agency (EPA) is presently developing secondary air quality standards for protection of ecosystems against the detrimental effects of nitrogen deposition (US EPA, 2008). This requires a better understanding of nitrogen deposition over the US in its various forms and including contributions from sources both natural and anthropogenic, foreign and domestic. We use here a nested version of the global GEOS-Chem chemical transport model (CTM) to address these issues.

The anthropogenic contribution to nitrogen deposition is mainly driven by emissions of nitrogen oxide radicals $\left(\mathrm{NO}_{\mathrm{x}} \equiv \mathrm{NO}+\mathrm{NO}_{2}\right)$ and ammonia $\left(\mathrm{NH}_{3}\right)$. These species also have natural sources. $\mathrm{NO}_{\mathrm{x}}$ is emitted to the atmosphere by 
combustion, microbial activity in soils, and lightning. In the atmosphere, $\mathrm{NO}_{\mathrm{x}}$ is oxidized to nitric acid $\left(\mathrm{HNO}_{3}\right)$ and organic nitrates on a time scale of less than a day. These can be deposited to ecosystems by direct uptake (dry deposition). In addition, $\mathrm{HNO}_{3}$ is highly soluble in water and is scavenged efficiently by precipitation (wet deposition). $\mathrm{NH}_{3}$ is emitted to the atmosphere by agriculture (mostly animal husbandry and fertilizer use), natural terrestrial and marine ecosystems, and fires. $\mathrm{NH}_{3}$ in the atmosphere can combine with $\mathrm{H}_{2} \mathrm{SO}_{4}$ (from $\mathrm{SO}_{2}$ oxidation) and $\mathrm{HNO}_{3}$ to produce ammonium sulfate and nitrate particles. Dry deposition is fast for gaseous $\mathrm{NH}_{3}$ but slow for ammonium particles, while wet deposition is efficient for both.

The lifetime of fixed nitrogen in the atmosphere is sufficiently short that most of the nitrogen deposition for a large country such as the US is expected to be of domestic origin. However, transboundary transport including on intercontinental scales can also be significant (Asman et al., 1998; Dentener et al., 2006; Sanderson et al. 2008). A number of studies have estimated an export efficiency of 20-30\% for nitrogen oxides $\left(\mathrm{NO}_{\mathrm{y}} \equiv \mathrm{NO}_{\mathrm{x}}\right.$ and its oxidation products) emitted in the US (Jacob et al., 1993; Kasibhatla et al., 1993; Liang et al., 1998; Li et al., 2004). No analysis has been conducted so far on the relative contributions from domestic, foreign, and natural sources to the different forms of nitrogen deposition over the US.

Here we use a nested continental scale version of the GEOS-Chem global CTM (Y. Wang et al., 2004; Chen et al., 2009) with horizontal resolution of $1 / 2^{\circ} \times 2 / 3^{\circ}$ over North America and $2^{\circ} \times 2.5^{\circ}$ for the rest of the world. Threeyear GEOS-Chem simulations (2006-2008) are conducted to quantify the sources and processes contributing to nitrogen deposition to the US. We present an extensive evaluation for 2006 with surface measurements of wet deposition fluxes, $\mathrm{HNO}_{3}$ and aerosol concentrations, and satellite observations of $\mathrm{NO}_{2}$. We quantify the contributions to nitrogen deposition from wet vs. dry processes and from individual nitrogen species. We also separate the contributions from domestic anthropogenic, foreign anthropogenic, and natural sources.

\section{The GEOS-Chem nested-grid model}

\subsection{General description}

The GEOS-Chem 3-D global chemical transport model (v802-03; http://geos-chem.org) was originally described by Bey et al. (2001) and Park et al. (2004). The model here is driven by GEOS-5 assimilated meteorological data for 20062008 from the NASA Global Modeling and Assimilation Office (GMAO). The GEOS-5 data are available with a temporal resolution of 6 hours ( 3 hours for surface variables and mixing depths), a horizontal resolution of $1 / 2^{\circ}$ latitude by $2 / 3^{\circ}$ longitude, and 72 vertical layers from the surface to 0.01 $\mathrm{hPa}$. The lowest 5 layers are centered at 70, 200, 330, 470, and $600 \mathrm{~m}$ for a column above sea level. We use a nested version of GEOS-Chem (Wang et al., 2004; Chen et al., 2009) with the native $1 / 2^{\circ} \times 2 / 3^{\circ}$ horizontal resolution over North America and adjacent oceans $\left(140^{\circ}-40^{\circ} \mathrm{W}, 10^{\circ}-70^{\circ} \mathrm{N}\right)$, and $2^{\circ} \times 2.5^{\circ}$ horizontal resolution for the rest of the world. Zhang et al. (2011) previously used the exact same model to estimate policy-relevant background ozone in surface air over the US.

The model includes a detailed simulation of tropospheric ozone- $\mathrm{NO}_{\mathrm{x}}$-hydrocarbon-aerosol chemistry, as recently described for example by Mao et al. (2010). Formation of organic nitrates from the oxidation of biogenic isoprene emitted by vegetation can be a significant sink for $\mathrm{NO}_{\mathrm{x}}$ in the model (Horowitz et al., 1998). We assume that these isoprene nitrates are removed by wet and dry deposition at the same deposition velocity as $\mathrm{HNO}_{3}$ and do not regenerate $\mathrm{NO}_{\mathrm{x}}$. Earlier versions of GEOS-Chem did not explicitly describe isoprene nitrates, treating them instead as $\mathrm{HNO}_{3}$ (Bey et al., 2001). Here we describe them explicitly in order to compare simulated $\mathrm{HNO}_{3}$ with observations and to quantify the contribution of isoprene nitrates to dry deposition.

Aerosol and gas-phase chemistry in GEOS-Chem are coupled through gas-aerosol partitioning of semi-volatile species including $\mathrm{NH}_{3}$ and $\mathrm{HNO}_{3}$, heterogeneous aerosol chemistry parameterized as reactive uptake coefficients (Jacob, 2000), and aerosol effects on photolysis rates (Martin et al., 2003). Partitioning of total $\mathrm{NH}_{3}$ and $\mathrm{HNO}_{3}$ between gas and aerosol phases is estimated with the RPMARES thermodynamic equilibrium model (Binkowski and Roselle, 2003). The reactive uptake coefficients $\gamma_{\mathrm{N}_{2}} \mathrm{O}_{5}$ for $\mathrm{N}_{2} \mathrm{O}_{5}$ in aerosols are from Evans and Jacob (2005), reduced by a factor of 10 as tested by Macintyre and Evans (2010). The resulting annual mean value of $\gamma_{\mathrm{N}_{2} \mathrm{O}_{5}}$ in surface air over the contiguous US is 0.003 , comparable to measured values in the range of 0.0005-0.006 (Brown et al., 2009; Bertram et al., 2009).

We conduct three-year GEOS-Chem simulations for 2006-2008. We first conduct the global simulation at $2^{\circ} \times 2.5^{\circ}$ resolution, and archive the output at 3-h temporal resolution for use as boundary conditions in the nested model. Output from the nested model does not affect the global simulation (one-way nesting).

\subsection{Deposition}

Wet deposition for aerosols follows the scheme described by Liu et al. (2001), with adaptation to soluble gases described by Mari et al. (2000) and Amos et al. (2012). The scheme includes scavenging in convective updrafts as well as in-cloud and below-cloud scavenging from large-scale precipitation. In warm (liquid) clouds with $T>268 \mathrm{~K}$, aerosols are assumed to be $100 \%$ incorporated in cloud droplets and gases are partitioned following Henry's law. In mixed (liquid/ice) clouds $(248<T<268 \mathrm{~K})$, where precipitation takes place by riming, aerosols are retained in the rime ice while gases are retained with varying efficiencies (unity for $\mathrm{HNO}_{3}$ but 0.05 for $\mathrm{NH}_{3}$; 
Table 1. Mean daytime dry deposition velocities over the contiguous US ${ }^{\mathrm{a}}$.

\begin{tabular}{|c|c|}
\hline Species & $v_{\mathrm{d}}\left(\mathrm{cm} \mathrm{s}^{-1}\right)$ \\
\hline $\mathrm{NH}_{3}$ & $0.65 \pm 0.40$ \\
\hline Aerosol $\mathrm{NH}_{4}^{+}$ & $0.15 \pm 0.03$ \\
\hline $\mathrm{HNO}_{3}$ & $2.7 \pm 1.5$ \\
\hline $\mathrm{N}_{2} \mathrm{O}_{5}$ & $2.7 \pm 1.5$ \\
\hline Isoprene nitrates & $2.7 \pm 1.5$ \\
\hline $\mathrm{NO}_{2}$ & $0.36 \pm 0.22$ \\
\hline PANs ${ }^{b}$ & $0.32 \pm 0.20$ \\
\hline alkyl nitrates & $0.32 \pm 0.20$ \\
\hline Aerosol $\mathrm{NO}_{3}^{-}$ & $0.15 \pm 0.03$ \\
\hline \multicolumn{2}{|c|}{$\begin{array}{l}\text { annual mean daytime ( } 10-16 \text { local time) } \\
\text { values computed in GEOS-Chem for the } \\
\text { ensemble of } 1 / 2^{\circ} \times 2 / 3^{\circ} \text { grid squares covering } \\
\text { the contiguous US and for the midpoint of } \\
\text { the lowest grid level }(\sim 70 \mathrm{~m} \text { above the } \\
\text { surface). Standard deviations describe the } \\
\text { spatial variability of the annual means. } \\
\text { b Peroxyacetyl nitrate (PAN) and higher } \\
\text { peroxyacyl nitrates. }\end{array}$} \\
\hline
\end{tabular}

Wang et al. (2008)). In cold (ice) clouds $(T<248 \mathrm{~K})$, both aerosols and $\mathrm{HNO}_{3}$ are scavenged with $100 \%$ efficiency $\left(\mathrm{HNO}_{3}\right.$ is taken up as a monolayer; Abbatt (1997)), while $\mathrm{NH}_{3}$ is not scavenged.

Dry deposition of gases and aerosols is simulated with a standard big-leaf resistance-in-series model (Wesely, 1989). The dry deposition flux $F_{\mathrm{d}}$ out of the lowest model layer (midpoint $z_{1} \approx 70 \mathrm{~m}$ above the surface) is calculated as:

$F_{d}=n_{\mathrm{a}} C\left(z_{1}\right) v_{d}\left(z_{1}\right)$

where $n_{\mathrm{a}}$ (molecules $\mathrm{cm}^{-3}$ ) is the number density of air, $C\left(z_{1}\right)$ is the mixing ratio of the depositing species at height $z_{1}$, and $v_{\mathrm{d}}$ is its deposition velocity $\left(\mathrm{cm} \mathrm{s}^{-1}\right)$ at that height. The deposition velocity is a function of the local meteorological condition and surface type, as given by:

$v_{d}\left(z_{1}\right)=\left(R_{a}\left(z_{1}, z_{0}\right)+R_{b}+R_{c}\right)^{-1}$

Here $R_{a}\left(z_{1}, z_{0}\right)$ is the aerodynamic resistance to turbulent transfer from $z_{1}$ to the roughness height $z_{0}$ close to the surface where turbulence vanishes, $R_{\mathrm{b}}$ is the boundary layer resistance to molecular diffusion from $z_{0}$ to the actual surface, and $R_{\mathrm{c}}$ is the canopy or surface uptake resistance.

Table 1 lists the annual mean daytime (10:00-16:00 local time) dry deposition velocities for different species computed in the model over the contiguous US. Values average $2.7 \pm 1.5 \mathrm{~cm} \mathrm{~s}^{-1}$ for $\mathrm{HNO}_{3}, \mathrm{~N}_{2} \mathrm{O}_{5}$, and isoprene nitrates; $0.65 \pm 0.40 \mathrm{~cm} \mathrm{~s}^{-1}$ for $\mathrm{NH}_{3}$; and $0.15-0.36 \mathrm{~cm} \mathrm{~s}^{-1}$ for aerosols, $\mathrm{NO}_{2}$, peroxyacetyl nitrate (PAN), and other organic nitrates. Other nitrogen species are not significantly removed by dry deposition. Model values are consistent with experimental studies, which report daytime dry deposition velocities to land in the $2-10 \mathrm{~cm} \mathrm{~s}^{-1}$ range for $\mathrm{HNO}_{3}$ (Sievering et
Table 2. $\mathrm{NO}_{\mathrm{x}}$ and $\mathrm{NH}_{3}$ emissions over the contiguous $\mathrm{US}^{\mathrm{a}}$.

\begin{tabular}{lll}
\hline & Source type & Emission $\left(\mathrm{Tg} \mathrm{N} \mathrm{a}^{-1}\right)$ \\
\hline $\mathrm{NO}_{\mathrm{x}}$ & Total & 6.7 \\
& Anthropogenic & 5.3 \\
& Lightning & 0.63 \\
& Soil & 0.41 \\
& Aircraft & 0.13 \\
& Fertilizer use & 0.12 \\
& Open fires & 0.055 \\
$\mathrm{NH}_{3}$ & Total & 2.9 \\
& Anthropogenic & 2.3 \\
& Natural & 0.56 \\
\hline
\end{tabular}

${ }^{a}$ Annual GEOS-Chem emissions for 2006-2008.

al., 2001; Horii et al., 2005), and in the $0.1-1.0 \mathrm{~cm} \mathrm{~s}^{-1}$ range for PAN (Doskey et al., 2004; Turnipseed et al. 2006; Wolfe et al., 2009). Biosphere-atmosphere exchange of $\mathrm{NO}_{\mathrm{x}}$ and $\mathrm{NH}_{3}$ is bi-directional (Sutton et al., 1998; Lerdau et al., 2000; Ellis et al., 2011), but is treated here as uncoupled emission and deposition processes. The fluxes to the surface are parameterized as uni-directional dry deposition, and the fluxes back to the atmosphere are included as part of natural emissions.

\subsection{Emissions}

A description of $\mathrm{NO}_{\mathrm{x}}$ emissions in the model is given in Zhang et al. (2011). We use global anthropogenic emissions of $\mathrm{NO}_{\mathrm{x}}, \mathrm{CO}$, volatile organic compounds (VOCs), and $\mathrm{SO}_{2}$ from the EDGAR inventory (Olivier and Berdowski, 2001), and global anthropogenic emissions of $\mathrm{NH}_{3}$ from GEIA (Bouwman et al., 1997). The global inventories are replaced with regional emission inventories including EPA NEI-2005 for the US, the CAC inventory for Canada (http: //www.ec.gc.ca/pdb/cac/cac_home_e.cfm), BRAVO for Mexico (Kuhns et al., 2005), EMEP for Europe (Vestreng and Klein, 2002), and Zhang et al. (2009) for Asia. The US anthropogenic emissions of $\mathrm{NH}_{3}$ from NEI-2005 are further modified to match surface total reduced nitrogen concentrations as described below. These global and regional inventories are scaled to the simulation year (2006-2008) based on the energy statistics described by van Donkelaar et al. (2008), except for NEI-2005 that is fixed for the year 2005. The model also includes global $\mathrm{NO}_{\mathrm{x}}$ emissions from fertilizer use and aircraft based on Yienger and Levy (1995) and Baughcum et al. (1996), respectively.

Natural $\mathrm{NO}_{\mathrm{x}}$ sources include lightning, soil, and open fires. $\mathrm{NO}_{\mathrm{x}}$ emissions from lightning are computed using the cloud top height parameterization of Price and Rind (1992), and vertically distributed following Pickering et al. (1998). The spatial distribution of lightning flashes is constrained with the 10-yr averaged OTD/LIS satellite observations as described by Sauvage et al. (2007). The $\mathrm{NO}_{\mathrm{x}}$ 

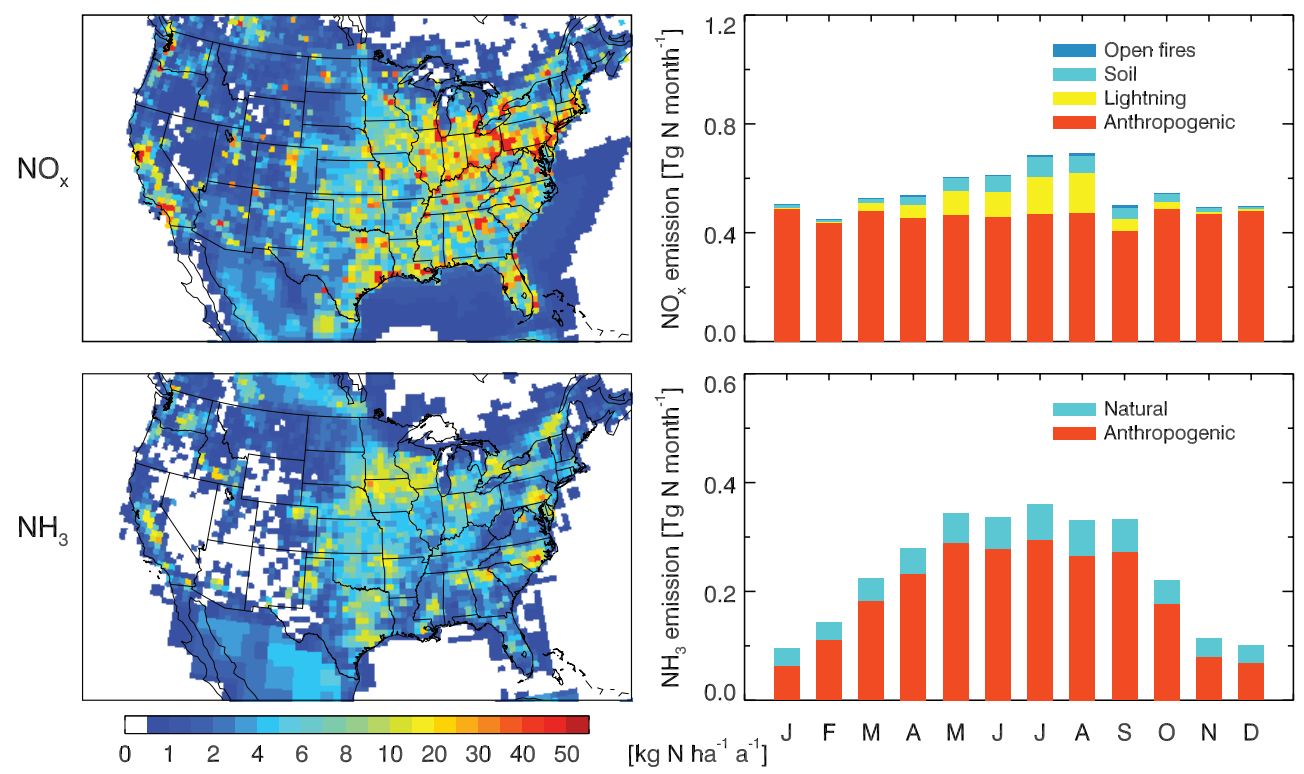

Fig. 1. $\mathrm{NO}_{\mathrm{x}}$ and $\mathrm{NH}_{3}$ emissions in 2006-2008. The left panels show annual total emissions at the $1 / 2^{\circ} \times 2 / 3^{\circ}$ resolution of GEOS-Chem . The right panels show seasonal variations for each source type over the contiguous US. Annual totals by source type are given in Table 2.
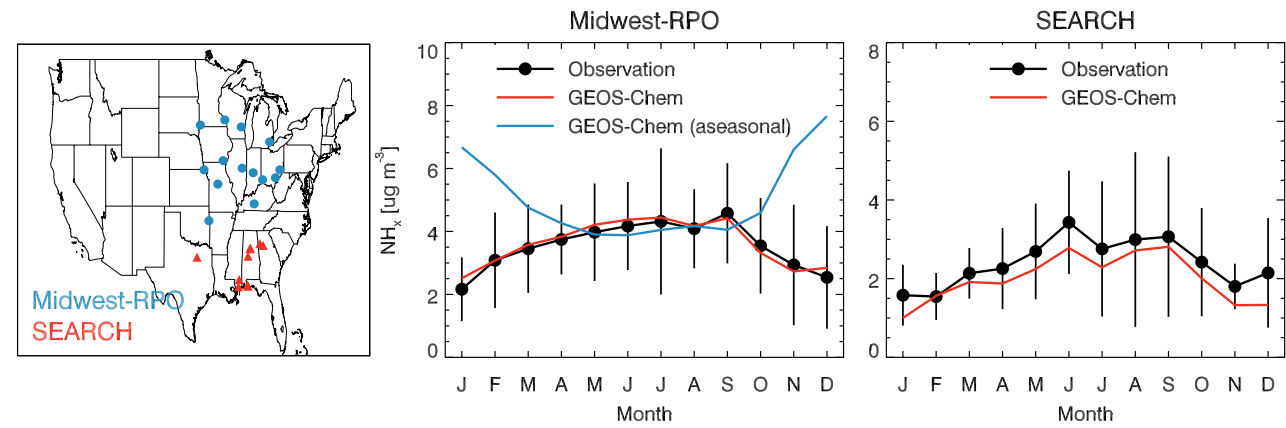

Fig. 2. Atmospheric concentrations of total reduced nitrogen $\left(\mathrm{NH}_{\mathrm{x}} \equiv \mathrm{NH}_{3}+\mathrm{NH}_{4}^{+}\right)$at the Midwest-RPO and SEARCH networks. Site locations are shown in the left panel. Monthly mean concentrations averaged across all sites of each network are shown in the central and right panels. Observations (black) are compared to model results using the $\mathrm{NEI} \mathrm{NH}_{3}$ anthropogenic emissions with no seasonal variation (blue line in the central panel) and with seasonal variation fitted to the Midwest-RPO data (red lines). The Midwest-RPO and SEARCH data are for 2004-2005 and 2006, respectively, and model results are for 2006. Vertical bars represent standard deviations in the observed monthly means for individual sites and years.

yield is estimated to be $500 \mathrm{~mol}$ per flash at northern midlatitudes, and 125 mol per flash in the tropics (Hudman et al., 2007), and this gives a global lightning source of $6 \mathrm{Tg} \mathrm{N} \mathrm{a}^{-1}$ (Martin et al., 2007). Soil $\mathrm{NO}_{\mathrm{x}}$ emissions follow the algorithm of Yienger and Levy (1995) with canopy reduction factors (Wang et al., 1998). Open fires emissions are from the monthly GFED-v2 inventory (van der Werf et al., 2006). Natural $\mathrm{NH}_{3}$ emissions from soil, vegetation, and the oceans are from the GEIA inventory (Bouwman et al., 1997). Biogenic VOC emissions, which are important for the conversion of $\mathrm{NO}_{\mathrm{x}}$ to organic nitrates, are from MEGAN (Guenther et al., 2006).

Figure 1 shows the spatial and seasonal distribution of US $\mathrm{NO}_{\mathrm{x}}$ emissions and Table 2 gives annual totals from each source over the contiguous US. Anthropogenic sources (5.6 $\mathrm{Tg} \mathrm{N} \mathrm{a}^{-1}$ including fertilizer use and aircraft) account for $84 \%$ of the total $\mathrm{NO}_{\mathrm{x}}$ emissions. Natural sources from lightning, soil, and open fires account for $9.5 \%, 6.2 \%$, and $0.7 \%$, respectively. Natural contributions peak in summer, accounting for $39 \%$ of US $\mathrm{NO}_{\mathrm{x}}$ emissions in July.

Gilliland et al. $(2003,2006)$ and Pinder et al. (2006) previously found large seasonally varying errors in the US NEI emission inventory for $\mathrm{NH}_{3}$ by model comparison with observed wet deposition fluxes of ammonium $\left(\mathrm{NH}_{4}^{+}\right)$and atmospheric concentrations of total reduced nitrogen $\left(\mathrm{NH}_{\mathrm{x}} \equiv \mathrm{NH}_{3}\right.$ gas + ammonium aerosol). Here we use $\mathrm{NH}_{\mathrm{x}}$ measurements from two networks (Fig. 2, left panel) to constrain the seasonality of $\mathrm{NH}_{3}$ emissions: the Midwest Ammonia 
Monitoring Project managed by the Midwest Regional Planning Organization (RPO) for 2004-2005 (http://www.ladco. org), and the Southeastern Aerosol Research and Characterization (SEARCH) for 2006 (Edgerton et al., 2006). Figure 2 (central panel) compares observations to model results in a simulation with the August NEI-2005 $\mathrm{NH}_{3}$ emission applied to the whole year (no seasonality source). Results agree well with measurements in summer but are too high in winter, reflecting a lower $\mathrm{NH}_{3}$ emission in winter than that in summer, as would be expected in view of the temperature dependence of $\mathrm{NH}_{3}$ emission (Aneja et al., 2000). We fit monthly scaling factors as observed/simulated concentration ratios to the NEI emissions to correct the discrepancy shown in the central panel of Figure 2 and apply them nationwide. These scaling factors range from $0.9-1$ in summer to $0.2-0.4$ in winter. Independent comparison of the resulting model to the SEARCH data for 2006 (Fig. 2, right panel) shows good agreement and thus supports these seasonal scaling factors.

Figure 1 shows the spatial and seasonal distribution of US $\mathrm{NH}_{3}$ emissions with the above scaling factors applied, and Table 2 gives annual totals for each source. Emissions show a broad May-September maximum. The highest emissions are in areas of major livestock operations. Anthropogenic emissions $\left(2.3 \mathrm{Tg} \mathrm{Na}^{-1}, 81 \%\right)$ dominate over natural emissions $\left(0.56 \mathrm{Tg} \mathrm{N} \mathrm{a}^{-1}, 19 \%\right)$.

Our $\mathrm{NO}_{\mathrm{x}}$ and $\mathrm{NH}_{3}$ emission estimates can be compared with those of Smith and Mueller (2010), who implemented natural emission inventories into the CMAQ regional model for July 2002 . For a model domain $\left(130^{\circ}-70^{\circ} \mathrm{W}, 23^{\circ}-56^{\circ} \mathrm{N}\right)$ covering the contiguous US and large fractions of Canada and Mexico, they found natural emissions to contribute $44 \%$ of $\mathrm{NO}_{\mathrm{x}}$ emissions and $28 \%$ of $\mathrm{NH}_{3}$ emissions. Our results for July 2006 over the same CMAQ domain are comparable, with natural emission contributions of $40 \%$ for $\mathrm{NO}_{\mathrm{x}}$ and $24 \%$ for $\mathrm{NH}_{3}$. The largest difference is for open fire $\mathrm{NO}_{\mathrm{x}}$ emissions, which are a factor of 5 higher in Smith et al. (2010). The GFED-v2 fire emissions used in GEOS-Chem indicate that dry mass burned over the CMAQ domain was a factor of 4 higher in July 2002 than in July 2006, mostly due to large fires in eastern Canada in 2002.

\section{Deposition patterns and surface concentrations}

Figure 3a-c compares simulated and observed sulfate, ammonium, and nitrate wet deposition fluxes over the US and Canada for 2006. The observations are from the 251 sites of the National Atmospheric Deposition Program/National Trends Network (NADP/NTN; data available at https://nadp. isws.illinois.edu/) for the US, and 26 sites of the Canadian Air and Precipitation Monitoring Network (CAPMoN; data available at http://www.on.ec.gc.ca/natchem/index.aspx) for Canada. We use sulfate as a check on the wet deposition processes in the model since the $\mathrm{SO}_{2}$ source from coal combustion is well constrained by stack measurements. We summa- rize the comparison between the model $(M)$ and observations $(O)$ using the correlation coefficient, the normalized mean bias (NMB) computed as $\mathrm{NMB}=\frac{\sum_{i=1}^{N}\left(M_{i}-O_{i}\right)}{\sum_{i=1}^{N} O_{i}}$ for the $N$ sites, and the mean normalized bias $\mathrm{MNB}=\frac{1}{N} \sum_{i=1}^{N}\left(M_{i}-O_{i}\right) / O_{i}$. The NMB estimates the mean offset between the model and observations, while MNB provides a sensitive evaluation of the model performance for observed low values.

For all three species the model shows strong correlations with observations, no significant annual biases, and little seasonal bias. MNB and NMB generally agree within a few percent, except for some seasonal cases where MNB is $\sim 20 \%$ higher due to model overestimates of very low observations. Wet deposition generally peaks in summer for all three species, in the case of sulfate and nitrate because of higher $\mathrm{SO}_{2}$ and $\mathrm{NO}_{\mathrm{x}}$ oxidant concentrations, and in the case of ammonium because of higher ammonia emissions. The summer peak of nitrate wet deposition is particularly pronounced around the Gulf of Mexico where it reflects the seasonal maxima in both lightning and precipitation. Simulated nitrate wet deposition peaks in Michigan and southeastern Canada in winter, caused by transport of $\mathrm{HNO}_{3}$ and nitrate aerosols produced mostly from $\mathrm{N}_{2} \mathrm{O}_{5}$ hydrolysis. This winter maximum is less pronounced in the observations, suggesting that $\mathrm{N}_{2} \mathrm{O}_{5}$ hydrolysis in the model may be too fast as discussed further below. The model does not capture the observed high values of ammonium wet deposition in the upper Midwest, as previously noted by Fisher et al. (2011), likely because of regional underestimate of emissions. Our national scaling factors are derived from $\mathrm{NH}_{\mathrm{x}}$ measurements in the east (Fig. 2), and may fail to correct the regional emissions in the upper Midwest.

No routine direct measurements of dry deposition fluxes are available at US sites. However, the Clean Air Status and Trends Network (CASTNet) makes weekly integrated measurements of gas-phase $\mathrm{HNO}_{3}$ concentrations from which dry deposition fluxes can be estimated using modeled dry deposition velocities (Clarke et al., 1997). Figure 4 compares annual mean $\mathrm{HNO}_{3}$ concentrations from CASTNet with GEOS-Chem results in 2006. The model has a mean positive bias of $69 \%$, which is due in part to the vertical gradient of concentrations between the lowest model grid-point $\left(z_{1}=70 \mathrm{~m}\right)$ and the CASTNet measurement altitude $\left(z_{\mathrm{C}}=10 \mathrm{~m}\right)$. This gradient can be quantified from the resistance-in-series formulation for dry deposition used in GEOS-Chem. We re-express the deposition flux in Eq. (1) as

$F_{d}=n_{\mathrm{a}} C\left(z_{1}\right) v_{d}\left(z_{1}\right)=n_{\mathrm{a}} \frac{C\left(z_{1}\right)-C\left(z_{\mathrm{C}}\right)}{R_{a}\left(z_{1}, z_{\mathrm{C}}\right)}$

where $R_{a}\left(z_{1}, z_{C}\right)$ is the aerodynamic resistance between $z_{1}$ and $z_{\mathrm{C}}$. In the GEOS-Chem resistance-in-series formulation the aerodynamic resistance is calculated between $z_{1}$ and $z_{0}$ 


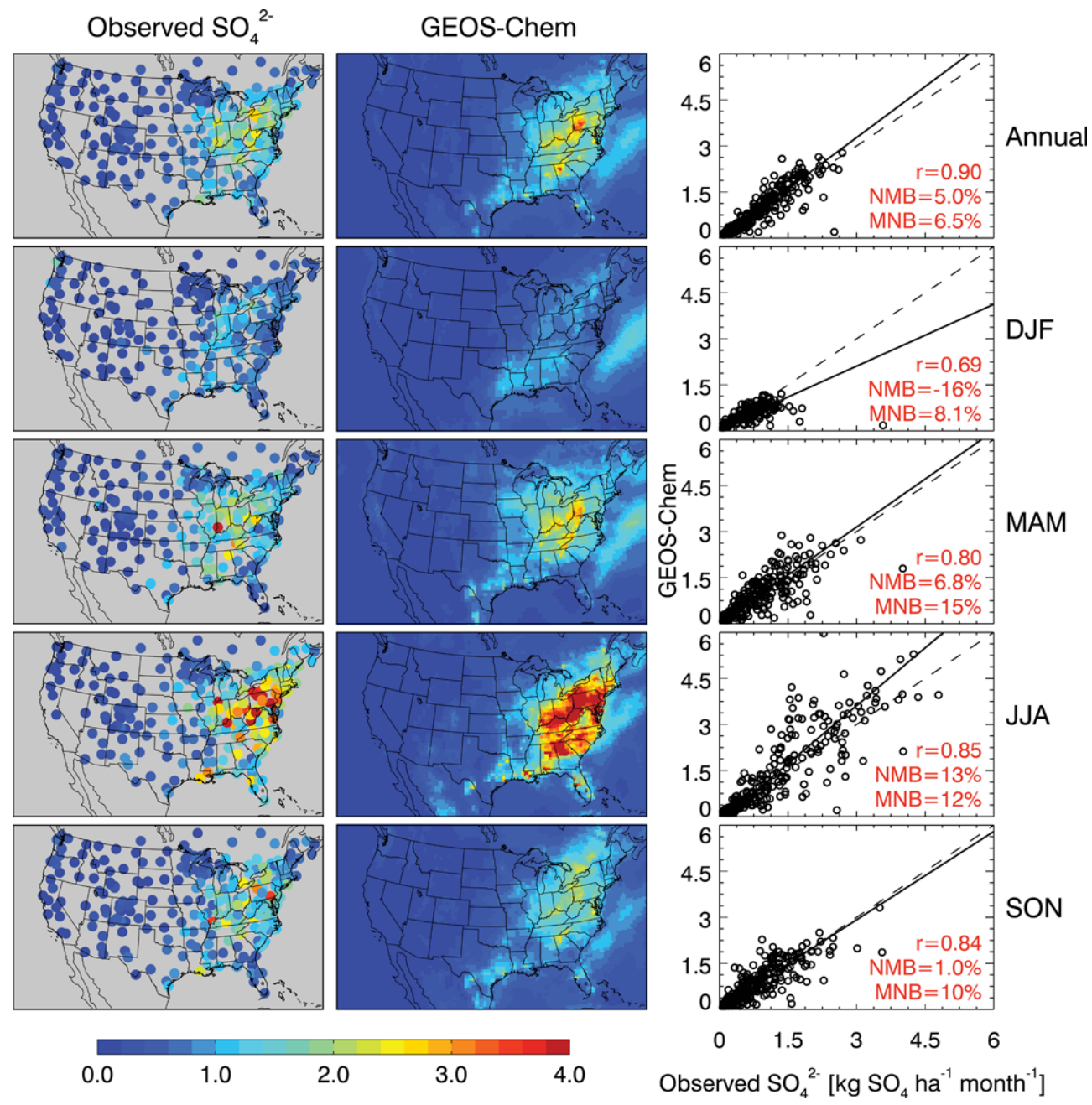

Fig. 3a. Annual and seasonal mean sulfate wet deposition fluxes measured at NADP and CAPMoN sites (left panels) and simulated by GEOS-Chem (central panels) in 2006. The right panels show scatter-plots of simulated versus observed values at individual sites. Correlation coefficients $(r)$, normalized mean biases (NMB), and mean normalized biases (MNB) are shown inset. Reduced-major-axis regression lines (solid) and the 1:1 lines (dash) are also shown.

(Eq. 2) using Monin-Obukhov similarity with momentum, and the same expression can be used to calculate the aerodynamic resistance between $z_{1}$ and $z_{\mathrm{C}}$ :,

$R_{a}\left(z_{1}, z_{C}\right)=\int_{z_{C}}^{z_{1}} \frac{\Phi(\zeta)}{k u^{*} \zeta} d \zeta$

Here $\zeta=z / L, L$ is the Monin-Obukhov length that is function of the local surface fluxes of momentum and sensible heat, $\Phi$ is a stability-dependent function (Businger et al., 1971), $u^{*}$ is the friction velocity, and $k$ is the von Karman constant. The implied model concentration at the CASTNet height $z_{\mathrm{C}}$ is related to the concentration at the lowest model gridpoint $z_{1}$ by:

$C\left(z_{\mathrm{C}}\right)=\left(1-R_{a}\left(z_{1}, z_{\mathrm{C}}\right) v_{d}\left(z_{1}\right)\right) C\left(z_{1}\right)$
We retrieved $\left(1-R_{a}\left(z_{1}, z_{\mathrm{C}}\right) v_{d}\left(z_{1}\right)\right)$ locally from GEOSChem, and applied it to $C\left(z_{1}\right)$ following Eq. (5). The right panel of Figure 4 shows the implied model $\mathrm{HNO}_{3}$ concentrations at $10 \mathrm{~m}$. They are on average $30 \%-40 \%$ lower than those at $70 \mathrm{~m}$, and the normalized mean bias relative to the CASTNet measurements reduces to $18 \%$. The model gradient between 70 and $10 \mathrm{~m}$ would be weaker than computed here if $\mathrm{HNO}_{3}$ remained in equilibrium with aerosol nitrate, which has low deposition velocity. Measurements by Sievering et al. (1994) over a forest in Germany indicate much weaker vertical gradients for aerosol nitrate than for $\mathrm{HNO}_{3}$, suggesting that equilibrium is not maintained on the short time scales associated with dry deposition.

The remaining model $\mathrm{HNO}_{3}$ bias (18\% annual mean) is driven by an overestimate in winter over the US industrial Midwest. The model has a NMB of $88 \%$ in winter and $-14 \%$ in summer. This is similar to the 


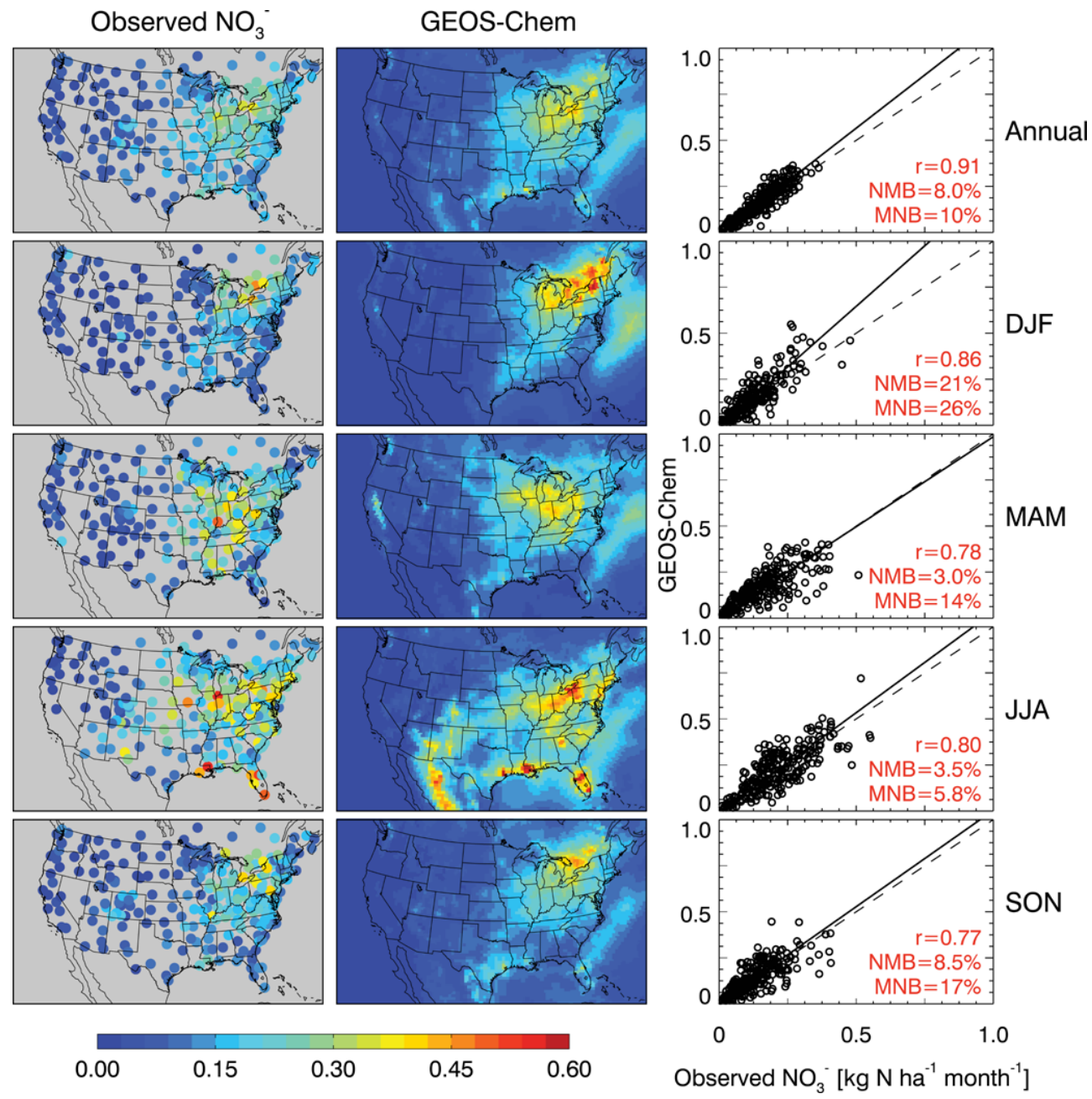

Fig. 3b. Same as Figure 3a but for nitrate $\left(\mathrm{NO}_{3}^{-}\right)$wet deposition.

previously mentioned model discrepancy with observed nitrate wet deposition fluxes. Model formation of $\mathrm{HNO}_{3}$ in winter is mostly from heterogeneous $\mathrm{N}_{2} \mathrm{O}_{5}$ hydrolysis in aerosols (Lamsal et al., 2010) and this process may be overestimated in the standard GEOS-Chem formulation (Evans and Jacob, 2005; Macintyre and Evans, 2010). The aerosol in winter has a large nitrate component, and laboratory studies have shown that $\gamma_{\mathrm{N}_{2} \mathrm{O}_{5}}$ is one order of magnitude smaller for nitrate than for sulfate aerosols because the nitrate inhibits $\mathrm{N}_{2} \mathrm{O}_{5}$ dissociation (Wahner et al., 1998; Mentel et al., 1999; Bertram and Thornton, 2009). This nitrate inhibition effect is not included in GEOS-Chem. In addition, recent field studies have shown that a significant fraction of nighttime $\mathrm{N}_{2} \mathrm{O}_{5}$ over the US reacts in chloride-containing aerosols to produce $\mathrm{ClNO}_{2}$, which photolyzes to $\mathrm{NO}_{2}$ the following morning and hence suppresses $\mathrm{HNO}_{3}$ formation (Roberts et al., 2009; Thornton et al., 2010).

We further evaluated the model simulation using observed aerosol concentrations of sulfate, nitrate, and ammonium from the CASTNet and EPA Air Quality System sites. Figure 5 compares observed and simulated annual mean values for 2006. The model reproduces the observed annual mean sulfate concentrations $(r=0.94-0.96)$ with only small biases $(-4$ to $-1 \%)$. This is important for constraining the model simulation of aerosol nitrate, which can form only if ammonia is in excess of sulfate. Observed ammonium and nitrate concentrations are highest in the Midwest, reflecting agricultural sources of $\mathrm{NH}_{3}$ that control the formation of ammonium nitrate aerosol. The model has some success in capturing the observed spatial distributions ( $r=0.82-0.94$ for ammonium, $0.60-0.70$ for nitrate) but is too high by $17-34 \%$ for ammonium and $40-81 \%$ for nitrate. The overestimate is most severe over the US Midwest in winter, supporting the hypothesis that $\mathrm{HNO}_{3}$ formation from $\mathrm{N}_{2} \mathrm{O}_{5}$ hydrolysis is too high in the model. The $\mathrm{HNO}_{3}$ overestimate leads more ammonia to partition to the aerosol phase and form ammonium nitrate aerosol. 

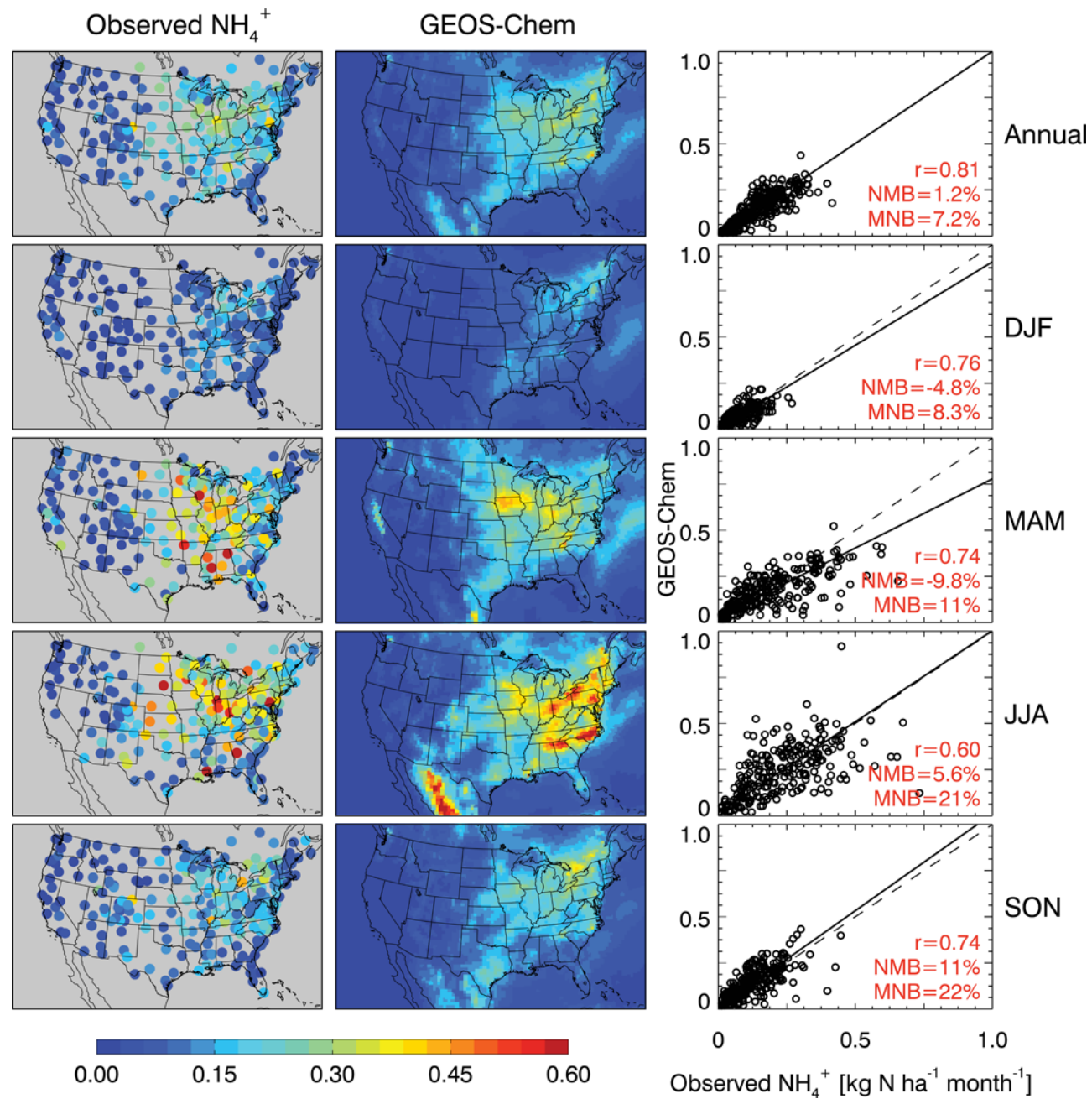

Fig. 3. Same as Figure 3a but for ammonium $\left(\mathrm{NH}_{4}^{+}\right)$wet deposition.

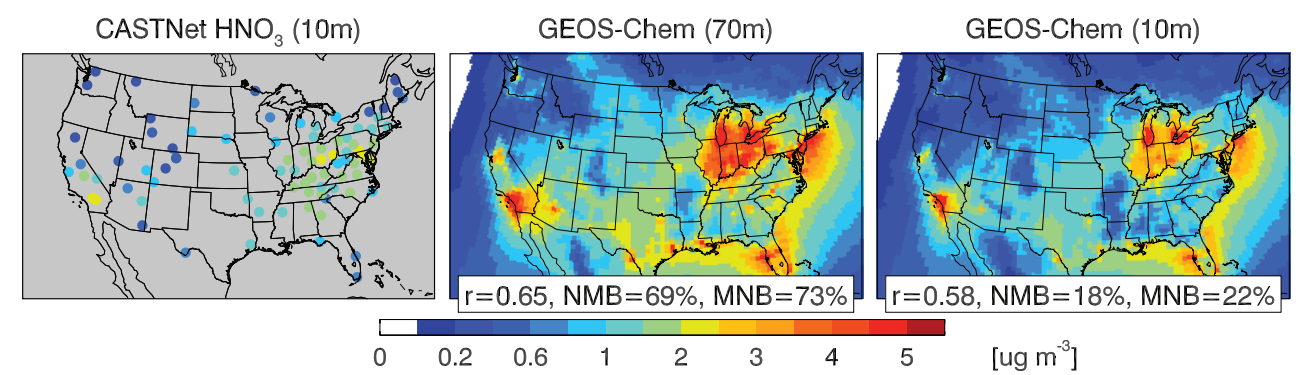

Fig. 4. Annual mean $\mathrm{HNO}_{3}$ concentrations in near-surface air in 2006. Measurements from the CASTNet sites at 10-m altitude (left panel) are compared to GEOS-Chem model values in the lowest model layer (70m; middle panel). The right panel shows $\mathrm{GEOS}_{-} \mathrm{Chem}_{\mathrm{HNO}}$ concentrations at $10 \mathrm{~m}$ inferred from aerodynamic resistances to dry deposition (see text). The correlation coefficients $(r)$, normalized mean biases (NMB), and mean normalized biases (MNB) are shown inset.

Finally, we evaluated the model with $\mathrm{NO}_{2}$ tropospheric column measurements from the Ozone Monitoring Instrument (OMI) aboard the Aura satellite. This provides an additional check on model $\mathrm{NO}_{\mathrm{x}}$ emissions as well as on the lifetime for $\mathrm{NO}_{\mathrm{x}}$ oxidation. The $\mathrm{OMI} \mathrm{NO}_{2}$ data (DOMINO v2.0) are from KNMI and are available at http://www.temis.nl (Boersma et al., 2011). Figure 6 compares the OMI tropospheric $\mathrm{NO}_{2}$ column with GEOS-Chem for MarchNovember 2006. We exclude the winter months due to large OMI retrieval errors over snow (O'Byrne et al., 2010). Model 

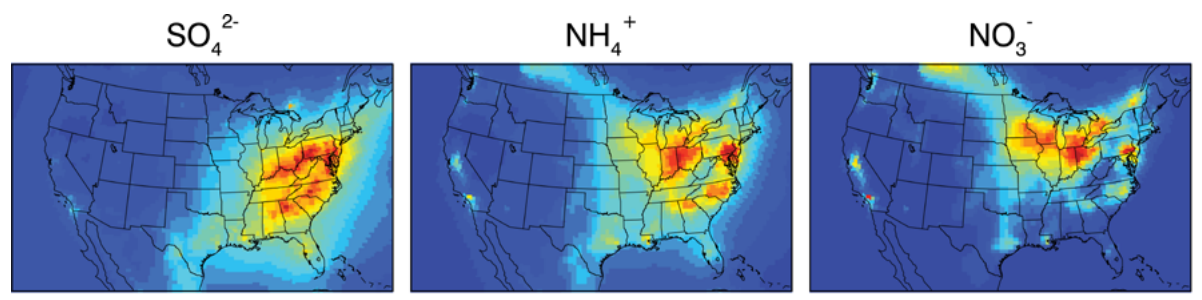

\section{GEOS-Chem}
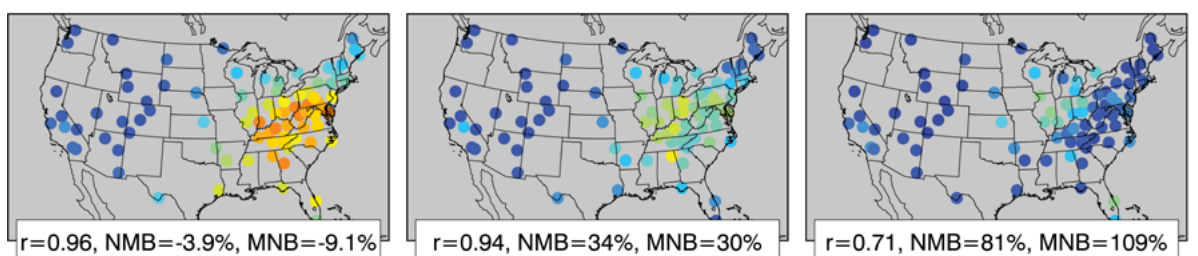

CASTNet
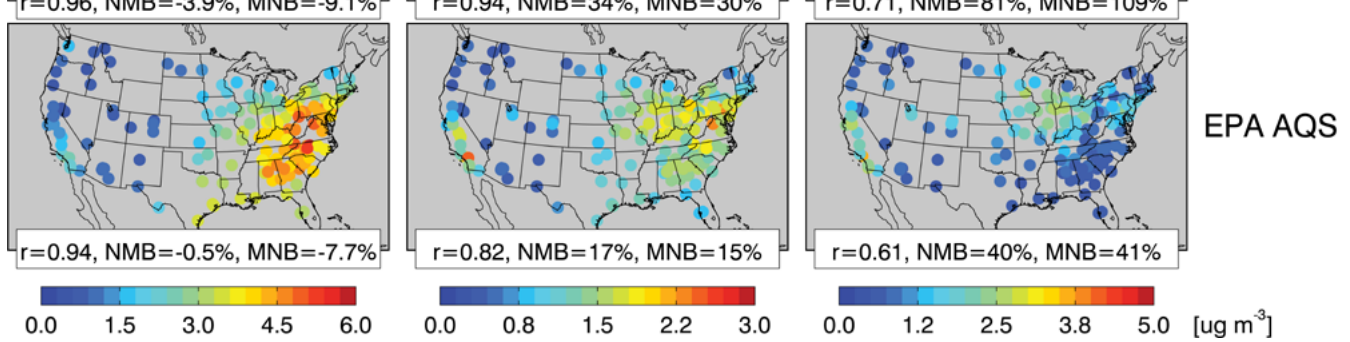

Fig. 5. Annual mean concentrations of sulfate (left), ammonium (middle), and nitrate (right) aerosol in surface air in 2006. Results from the GEOS-Chem model (top) are compared to observations from CASTNet (middle), and EPA AQS (bottom). Statistics for model comparisons to observations are shown inset as correlation coefficients $(r)$, normalized mean biases (NMB), and mean normalized biases (MNB).
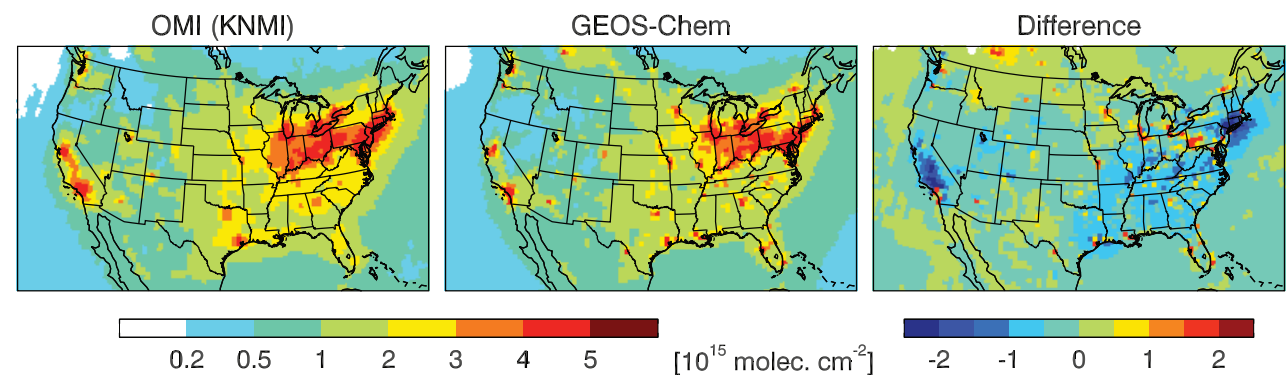

Fig. 6. Mean tropospheric $\mathrm{NO}_{2}$ columns in March-November 2006. OMI satellite observations mapped on the $1 / 2^{\circ} \times 2 / 3^{\circ}$ GEOS-Chem grid (left) are compared to GEOS-Chem results (center). The GEOS-Chem minus OMI difference is shown in the right panel.

results are sampled at the satellite overpass time (13:45 local time). The model closely reproduces the spatial distribution of $\mathrm{NO}_{2}$ tropospheric columns $(r=0.95)$, but there is a mean $12 \%$ low bias over the southeast US and $40 \%$ low bias over California.

\section{Nitrogen deposition processes}

We now examine the contributions of different processes to nitrogen deposition over the US. We focus here on quantifying the relative contributions from wet vs. dry deposition, from individual nitrogen species, and from domestic anthropogenic vs. other sources. A three-year average of model results (2006-2008) is used to account for interannual variabil- ity in nitrogen deposition. Relative interannual variability in the model is very small for the results presented here.

Figure 7 shows the annual wet and dry deposition fluxes of oxidized $\left(\mathrm{NO}_{\mathrm{y}}\right)$ and reduced $\left(\mathrm{NH}_{\mathrm{x}}\right)$ nitrogen, and Table 3 summarizes the annual total deposition amounts from each process and from individual species over the contiguous US. Dry deposition patterns closely follow emissions (Fig. 1). Wet deposition patterns depend on precipitation as well as on emissions. On the national scale, $\mathrm{NO}_{\mathrm{y}}$ is removed preferentially by dry rather than wet deposition ( 2.9 vs. $1.3 \mathrm{Tg} \mathrm{N} \mathrm{a}^{-1}$ ), while for $\mathrm{NH}_{\mathrm{x}}$ dry and wet deposition are comparable (1.0 vs. $1.3 \mathrm{Tg} \mathrm{N} \mathrm{a}{ }^{-1}$ ). The more efficient dry deposition for $\mathrm{NO}_{\mathrm{y}}$ reflects the high dry deposition velocity for $\mathrm{HNO}_{3}$ as shown in Table 1. Annually $\mathrm{HNO}_{3}$ deposition represents $55 \%$ of $\mathrm{NO}_{\mathrm{y}}$ dry deposition, $\mathrm{NO}_{2} 22 \%$, isoprene nitrates $9 \%$, PAN 

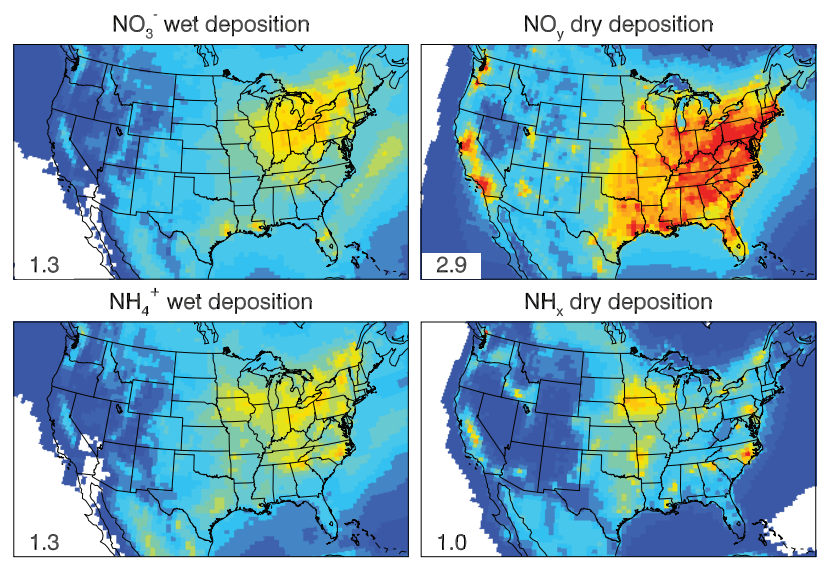

$\begin{array}{lllllllll}0.1 & 0.5 & 1 & 2 & 3 & 4 & 6 & 8 & 10\end{array}$

$\left[\mathrm{kg} \mathrm{N} \mathrm{ha}^{-1} \mathrm{a}^{-1}\right.$

Fig. 7. Simulated annual total fluxes of $\mathrm{NO}_{3}^{-}$wet deposition, $\mathrm{NO}_{y}$ dry deposition, $\mathrm{NH}_{4}^{+}$wet deposition, and $\mathrm{NH}_{\mathrm{x}}$ dry deposition. Values are 3-year means for 2006-2008. Annual totals over the contiguous US from each process are shown inset in unit of $\mathrm{Tg} \mathrm{N}^{-1}$.

Table 3. Nitrogen deposition over the contiguous US ${ }^{\mathrm{a}}$.

\begin{tabular}{lll}
\hline & Deposition process & Deposition $\left(\mathrm{Tg} \mathrm{N} \mathrm{a}^{-1}\right)$ \\
\hline $\mathrm{NO}_{y}$ & Total & 4.2 \\
& ${\text { Wet } \mathrm{NO}_{3}^{-}}$ & 1.3 \\
& ${\text { Dry } \mathrm{HNO}_{3}}$ & 1.6 \\
& Dry $\mathrm{NO}_{2}$ & 0.64 \\
& Dry isoprene nitrates & 0.26 \\
& Dry $\mathrm{N}_{2} \mathrm{O}_{5}$ & 0.18 \\
& Dry $\mathrm{PANs}^{-}$ & 0.086 \\
& Dry $\mathrm{NO}_{3}^{-}$aerosol & 0.068 \\
& Dry alkyl nitrates & 0.024 \\
$\mathrm{NH}_{\mathrm{x}}$ & Total & 2.3 \\
& Wet $\mathrm{NH}_{4}^{+}$ & 1.3 \\
& Dry $\mathrm{NH}_{3}$ & 0.83 \\
& Dry $\mathrm{NH}_{4}^{+}$aerosol & 0.20 \\
\hline
\end{tabular}

a Annual total nitrogen deposition for 2006-2008 computed with the GEOS-Chem model.

$3.0 \%$, and nitrate aerosol $2.3 \%$. Dry deposition of $\mathrm{NH}_{\mathrm{x}}$ is mainly through gaseous $\mathrm{NH}_{3}$ (82\% of $\mathrm{NH}_{\mathrm{x}}$ dry deposition), reflecting its high deposition velocity relative to ammonium aerosol. The previously mentioned CMAQ simulation of Smith and Mueller (2010) simulates an annual $\mathrm{NO}_{y}$ dry deposition flux of $1.9 \mathrm{Tg} \mathrm{N} \mathrm{a}^{-1}$ in 2002 over the contiguous United States, with $70 \%$ contributed by $\mathrm{HNO}_{3}$ dry deposition (J. W. Mallard and S. F. Mueller, personal communication, 2012). Future work is needed to understand the differences between the two models.

Holland et al. (2005) previously estimated annual nitrogen deposition fluxes over the contiguous US from the NADP wet deposition fluxes of nitrate and ammonium, together with the CASTNet-derived dry deposition fluxes of $\mathrm{HNO}_{3}$, nitrate
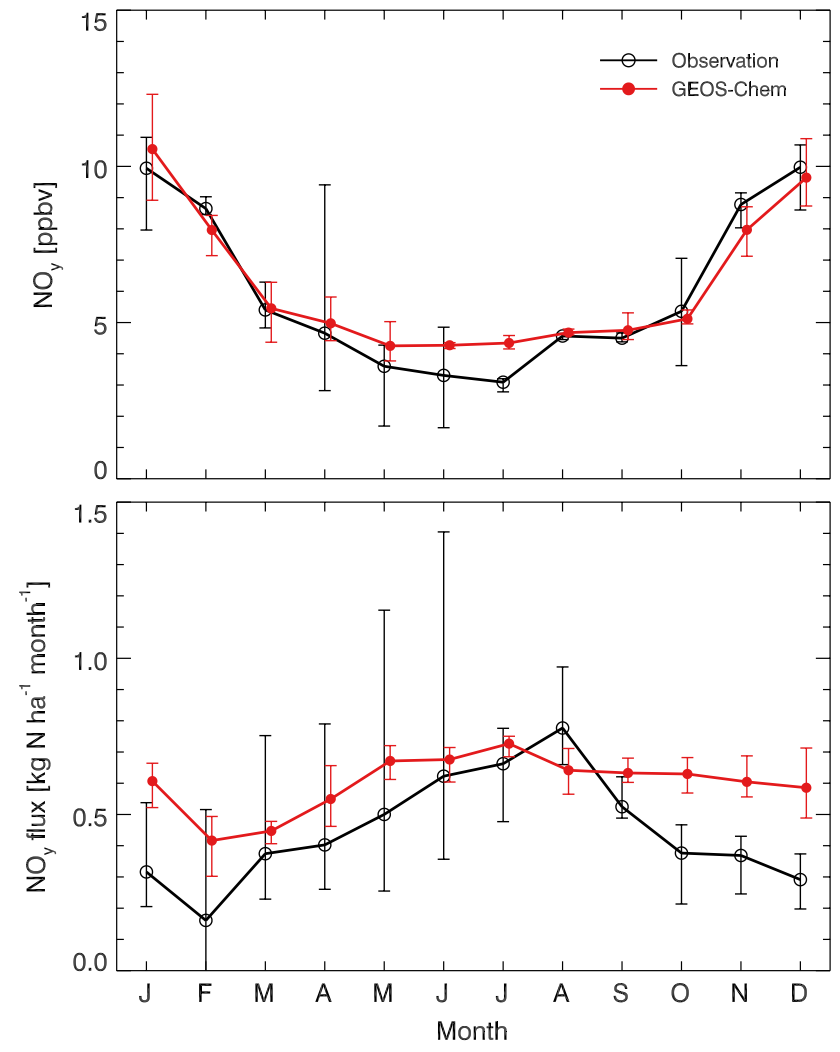

Fig. 8. Monthly $\mathrm{NO}_{\mathrm{y}}$ concentrations (top) and dry deposition fluxes (bottom) at Harvard Forest, Massachusetts $\left(42.53^{\circ} \mathrm{N}, 72.18^{\circ} \mathrm{W}\right)$. Concentration and eddy covariance flux measurements for 19992002 (black) are compared to model results averaged for 2006-2008 (red). The vertical bars indicate the range of the monthly mean values for the four years of measurements and three years of model results.

aerosol, and ammonium aerosol. Their wet deposition fluxes (1.28 and $1.08 \mathrm{Tg} \mathrm{N} \mathrm{a}^{-1}$ as $\mathrm{NO}_{\mathrm{y}}$ and $\mathrm{NH}_{\mathrm{x}}$ respectively) agree closely with our model results, but their dry deposition fluxes (1.20 and $0.18 \mathrm{Tg} \mathrm{N} \mathrm{a}^{-1}$ as $\mathrm{NO}_{\mathrm{y}}$ and $\mathrm{NH}_{\mathrm{x}}$ respectively) are much lower. The differences are in part because the CASTNet data do not account for dry deposition of $\mathrm{NO}_{2}$, organic nitrates, and $\mathrm{NH}_{3}$.

Simulated $\mathrm{NO}_{\mathrm{y}}$ dry deposition fluxes can be directly compared to eddy covariance $\mathrm{NO}_{\mathrm{y}}$ flux measurements at Harvard Forest $\left(42.53^{\circ} \mathrm{N}, 72.18^{\circ} \mathrm{W}\right)$, Massachusetts. Figure $8 \mathrm{com}-$ pares the monthly mean $\mathrm{NO}_{\mathrm{y}}$ concentration and eddy covariance flux measurements at Harvard Forest for 1999-2002 to model results for 2006-2008. Measured $\mathrm{NO}_{\mathrm{y}}$ concentrations peak in winter and are minimum in summer, with annual means of 6.0-6.2 ppbv. The model reproduces closely the observed values and their seasonal variation. Measured $\mathrm{NO}_{\mathrm{y}}$ fluxes peak in summer and are minimum in winter. The model has a weaker seasonality; it captures the summertime fluxes but is too high in fall and winter. The mean measured annual $\mathrm{NO}_{\mathrm{y}}$ deposition flux is $5.4 \mathrm{~kg} \mathrm{Nha}^{-1} \mathrm{a}^{-1}$, 


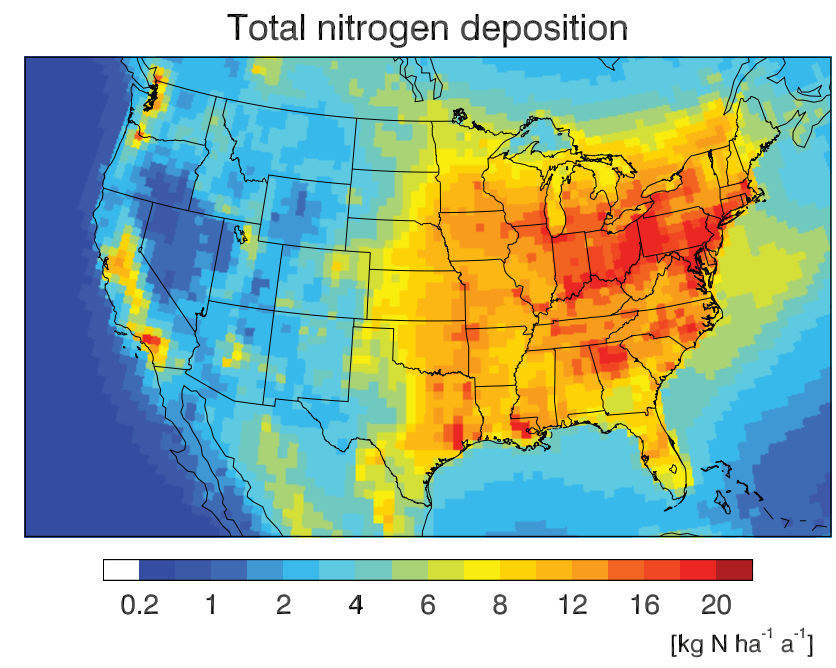

Fig. 9. Annual total nitrogen deposition fluxes. Values are GEOSChem averages for 2006-2008.

and the model is $33 \%$ higher $\left(7.2 \mathrm{~kg} \mathrm{Nha}^{-1} \mathrm{a}^{-1}\right)$. The measured flux was particularly high in $2000\left(8.1 \mathrm{~kg} \mathrm{~N} \mathrm{ha}^{-1} \mathrm{a}^{-1}\right)$, and had little variation for the other three years (4.2$4.4 \mathrm{~kg} \mathrm{Nha}^{-1} \mathrm{a}^{-1}$ ). Model results show little inter-annual variation for 2006-2008 (6.9-7.5 $\left.\mathrm{kg} \mathrm{N} \mathrm{ha}^{-1} \mathrm{a}^{-1}\right)$. The model overestimate of $\mathrm{NO}_{\mathrm{y}}$ dry deposition in fall and winter may reflect in large part an excessive $\mathrm{N}_{2} \mathrm{O}_{5}$ hydrolysis in aerosols, as discussed above. Sparks et al. (2008) measured $\mathrm{NO}_{\mathrm{y}}$ eddy flux measurements at Duke Forest $\left(35.97^{\circ} \mathrm{N}, 79.08^{\circ} \mathrm{W}\right)$, North Carolina and estimated an annual $\mathrm{NO}_{\mathrm{y}}$ dry deposition flux of $4.3 \mathrm{~kg} \mathrm{Nha}^{-1} \mathrm{a}^{-1}$ in 2003 . The model is too high $\left(7.2 \mathrm{~kg} \mathrm{Nha}^{-1} \mathrm{a}^{-1}\right)$ at that site, similar to the comparison at Harvard Forest. However, Sparks et al. (2008) stated that their $\mathrm{NO}_{\mathrm{y}}$ eddy flux measurements could be biased low by up to $35 \%$ due to loss of $\mathrm{HNO}_{3}$ within the instrument inlet.

Eddy covariance flux measurements of PAN have been reported at Duke Forest (Turnipseed et al., 2006), and at Blodgett Forest, California (Wolfe et al., 2009). Turnipseed et al. (2006) found that PAN deposition accounted for $20 \%$ of the daytime $\mathrm{NO}_{\mathrm{y}}$ deposition at Duke Forest in July 2003, but Wolfe et al. (2009) found only a $4 \%$ contribution at Blodgett Forest in August-October 2007 after correcting for the PAN thermal decomposition between the altitude of measurement and the surface. We find in GEOS-Chem that PAN contributes respectively $5 \%$ and $4 \%$ of $\mathrm{NO}_{y}$ dry deposition at the two sites in summer.

We find in the model that $4.2 \mathrm{Tg} \mathrm{N}$ of $\mathrm{NO}_{\mathrm{y}}$ and $2.3 \mathrm{Tg} \mathrm{N}$ of $\mathrm{NH}_{\mathrm{x}}$ are deposited annually over the contiguous US. Comparison to US emissions in Table 2 indicates an annual net export of $2.5 \mathrm{TgN}$ as $\mathrm{NO}_{\mathrm{y}}$ (38\% of $\mathrm{NO}_{\mathrm{x}}$ emissions) and $0.60 \mathrm{Tg} \mathrm{N}$ as $\mathrm{NH}_{\mathrm{x}}\left(21 \%\right.$ of $\mathrm{NH}_{3}$ emissions). Our results are consistent with Dentener et al. (2006), who found by averaging results from 23 chemical transport models that net export of $\mathrm{NO}_{\mathrm{y}}$ from the US amounts to $37 \%$ of US $\mathrm{NO}_{\mathrm{x}}$ emissions.
Table 4. Source contributions to nitrogen deposition over the contiguous US ${ }^{\mathrm{a}}$

\begin{tabular}{llll}
\hline Source & $\mathrm{NO}_{\mathrm{y}}$ & $\mathrm{NH}_{\mathrm{x}}$ & Total \\
\hline Anthropogenic & & & \\
$\quad$ Domestic & 3.4 & 1.6 & 5.0 \\
Foreign & 0.24 & 0.18 & 0.42 \\
Natural & 0.57 & 0.47 & 1.0 \\
\hline
\end{tabular}

a Nitrogen deposition fluxes from different sources computed by the GEOS-Chem model as described in the text. Values are annual total fluxes in unit of $\mathrm{Tg} \mathrm{Na}^{-1}$.

\section{Domestic, foreign, and natural contributions to nitrogen deposition}

Figure 9 shows the simulated spatial distribution of annual total (wet and dry) nitrogen deposition over the US. Nitrogen deposition is generally $>8 \mathrm{~kg} \mathrm{Nha}^{-1} \mathrm{a}^{-1}$ in the eastern US and $1-4 \mathrm{~kg} \mathrm{Nha}^{-1} \mathrm{a}^{-1}$ in remote areas of the west. It is highest in the industrial Midwest with regional values in excess of $15 \mathrm{~kg} \mathrm{Nha}^{-1} \mathrm{a}^{-1}$. Bobbink et al. (1998) and Bouwman et al. (2002) estimate a "critical load" threshold of $10 \mathrm{~kg} \mathrm{Nha}^{-1} \mathrm{a}^{-1}$ for sensitive ecosystems above which disturbance could be significant. In our simulation, $35 \%$ of the US land receives nitrogen deposition exceeding this load.

We separated the contributions to nitrogen deposition from domestic anthropogenic, foreign anthropogenic, and natural sources by conducting sensitivity simulations for 2006 with (1) US domestic $\mathrm{NH}_{3}$ and $\mathrm{NO}_{\mathrm{x}}$ anthropogenic emissions shut off, (2) global anthropogenic emissions shut off. Table 4 summarizes the budgets for the contiguous US. Domestic anthropogenic emissions account respectively for $81 \%$ and $71 \%$ of $\mathrm{NO}_{\mathrm{y}}$ and $\mathrm{NH}_{\mathrm{x}}$ deposition to the US (78\% of total nitrogen deposition). Foreign anthropogenic emissions contribute $6 \%$ of $\mathrm{NO}_{\mathrm{y}}$ deposition, $8 \%$ of $\mathrm{NH}_{\mathrm{x}}$ deposition, and $6 \%$ of the total deposition. Natural sources account for the rest: $13 \%$ of $\mathrm{NO}_{\mathrm{y}}$ deposition, $21 \%$ of $\mathrm{NH}_{\mathrm{x}}$ deposition, and $16 \%$ of total nitrogen deposition.

Figure 10 shows how these deposition enhancements and relative contributions vary by receptor region. The domestic anthropogenic contribution generally exceeds $70 \%$ in the east and in populated areas of the west, falling off to $50-70 \%$ in remote areas of the west. Foreign anthropogenic contributions are generally less than $10 \%$ but can rise up to $30 \%$ near the Canadian and Mexican borders. The rising $\mathrm{NO}_{\mathrm{x}}$ and $\mathrm{NH}_{3}$ emissions from oil production and agriculture in western Canada (Schindler et al., 2006) could significantly affect Montana and North Dakota. Natural source contributions are less than $10 \%$ in the eastern US and the West Coast, and about $20-30 \%$ in the intermountain West, with maximum contributions of $40 \%$ over the southwest US due to lightning emissions and over Idaho due to wildfires. 

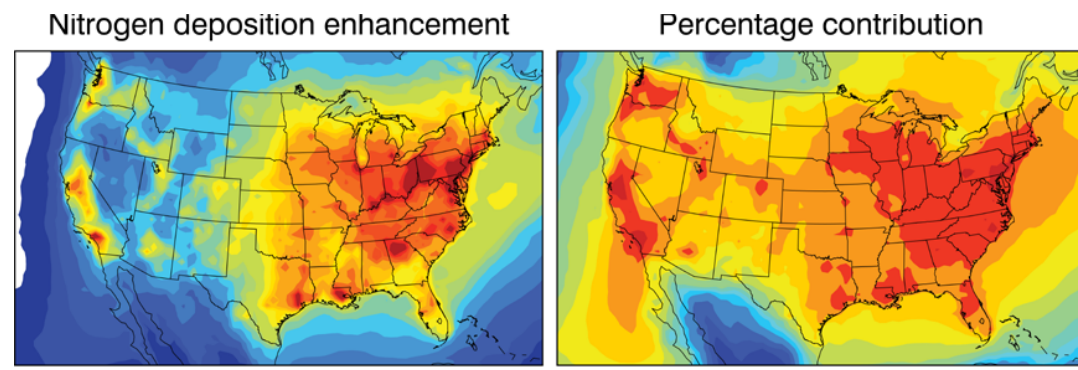

US

anthropogenic
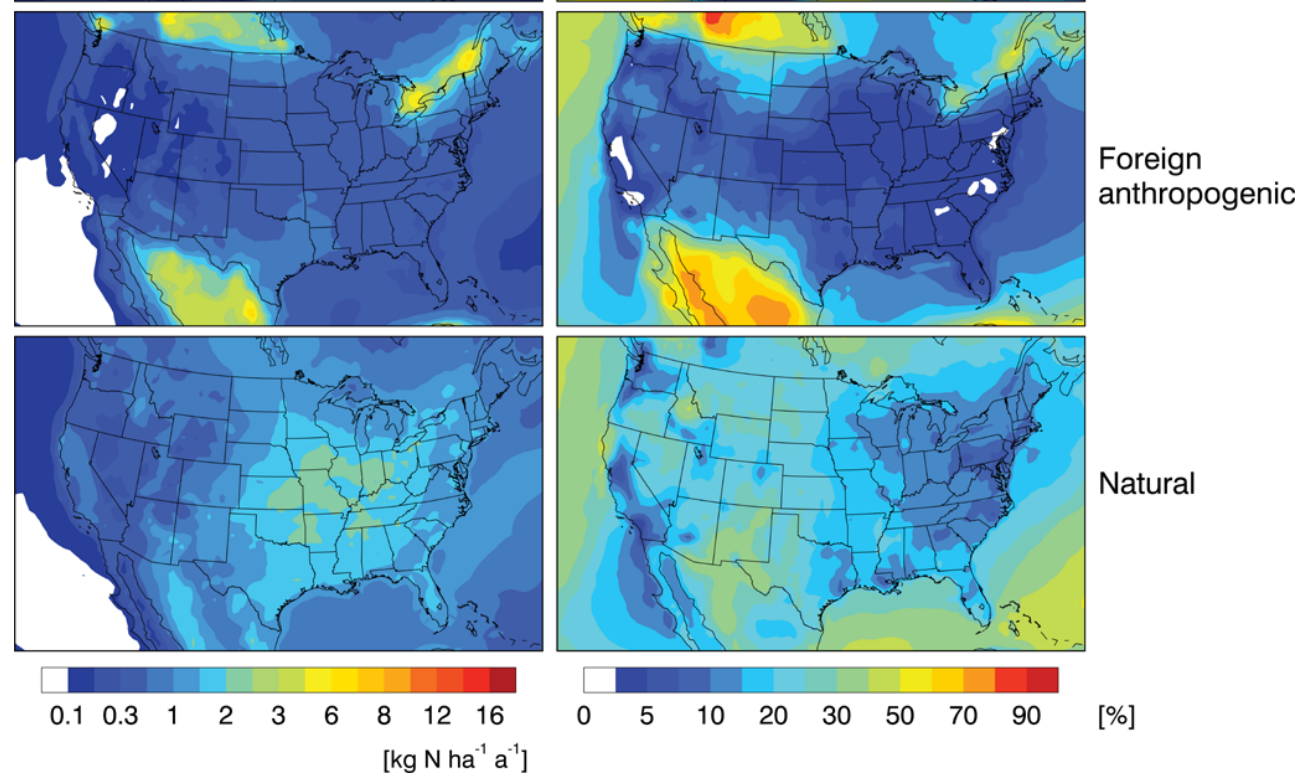

Fig. 10. Domestic anthropogenic, foreign anthropogenic, and natural contributions to annual nitrogen deposition over the contiguous US. Values are from GEOS-Chem sensitivity simulations for 2006 (see text) and are presented as both absolute and relative contributions.

\section{Conclusions}

We have presented a simulation of nitrogen deposition over the US in 2006-2008 using a nested-grid version of the GEOS-Chem global chemical transport model with $1 / 2^{\circ} \times 2 / 3^{\circ}$ horizontal resolution over North America and adjacent oceans $\left(140^{\circ}-40^{\circ} \mathrm{W}, 10^{\circ}-70^{\circ} \mathrm{N}\right)$, and $2^{\circ} \times 2.5^{\circ}$ horizontal resolution for the rest of the world. The model includes a detailed representation of oxidant-aerosol chemistry. Our focus was to quantify the processes and species contributing to nitrogen deposition over the contiguous US as well as the relative contributions of domestic anthropogenic, foreign anthropogenic, and natural sources.

Total $\mathrm{NO}_{\mathrm{x}}$ and $\mathrm{NH}_{3}$ emissions in the contiguous US in the model are 6.7 and $2.9 \mathrm{Tg} \mathrm{N} \mathrm{a}^{-1}$ respectively. Natural sources account for about $20 \%$ annually for both (up to $39 \%$ for $\mathrm{NO}_{\mathrm{x}}$ in summer). Previous studies (Gilliland et al., 2003, 2006; Pinder et al., 2006) identified large seasonal biases in US emission inventories for $\mathrm{NH}_{3}$. Our model imposes a seasonality of $\mathrm{NH}_{3}$ emissions fitted to surface $\mathrm{NH}_{\mathrm{X}}$ measurements from the Midwest RPO and SEARCH networks, such that emissions in winter are about a third those in summer. Successful simulation of observations for $\mathrm{NH}_{\mathrm{x}}$ concentrations and ammonium wet deposition fluxes lends support to the $\mathrm{NH}_{3}$ emissions used in the model, except in the upper Midwest where emissions appear to be too low.

We evaluated the model with an ensemble of relevant data sets for deposition fluxes and concentrations. The model reproduces the wet deposition fluxes of sulfate, nitrate and ammonium measured at the NADP sites in the US and the CAPMoN sites in Canada with high correlations and no significant bias. Comparison to observed $\mathrm{HNO}_{3}$ concentrations at CASTNet sites shows a mean positive model bias of $69 \%$, but we show that this largely reflects the expected concentration gradient between the CASTNet measurement altitude $(10 \mathrm{~m})$ and the midpoint of the lowest model layer $(70 \mathrm{~m})$. Correcting for this gradient reduces the mean model bias over the US to $18 \%$ and localizes it to the industrial Midwest in winter $(88 \%)$. Comparisons with aerosol measurements of sulfate, ammonium and nitrate at CASTNet and EPA-AQS networks show no significant biases for sulfate, but positive biases of $17-34 \%$ for ammonium and $40-81 \%$ for nitrate. The model reproduces closely the spatial pattern of satellite $\mathrm{NO}_{2}$ tropospheric column measurements from OMI with a $12 \%$ low bias over the Southeast US and $40 \%$ low bias over California. Comparison to multi-year eddy correlation 
measurements of $\mathrm{NO}_{\mathrm{y}}$ dry deposition fluxes at Harvard Forest, Massachusetts shows good agreement in summer but a factor of 2 high bias in winter.

The main model flaw identified through comparison to the ensemble of observations is excessive $\mathrm{HNO}_{3}$ production in winter. This production in the model is mainly from $\mathrm{N}_{2} \mathrm{O}_{5}$ hydrolysis in aerosols, with a mean reactive uptake coefficient $\gamma_{\mathrm{N}_{2} \mathrm{O}_{5}}=0.003$ averaged across all aerosol types (Evans and Jacob, 2005; Macintyre and Evans, 2010) that is not inconsistent with values inferred from field observations in summer (Brown et al., 2009). However, the model does not account for inhibition of hydrolysis by aerosol nitrate (Davis et al., 2008; Bertram and Thornton, 2009), which would be important in winter when nitrate is a major constituent of the aerosol. It also does not account for reaction of $\mathrm{N}_{2} \mathrm{O}_{5}$ with chloride aerosol (Roberts et al., 2009; Thornton et al., 2010), which would decrease the $\mathrm{HNO}_{3}$ yield. These effects should be included in future versions of the model.

We analyzed model results for 2006-2008 to quantify the processes contributing to nitrogen deposition. We find that 6.5 Tg N a ${ }^{-1}$ is deposited over the contiguous US: $4.2 \mathrm{Tg} \mathrm{N}$ as $\mathrm{NO}_{\mathrm{y}}$ and $2.3 \mathrm{Tg} \mathrm{N}$ as $\mathrm{NH}_{\mathrm{x}}$. Dry deposition accounts for $70 \%$ of total deposition for $\mathrm{NO}_{\mathrm{y}}$ and $43 \%$ for $\mathrm{NH}_{\mathrm{x}}$. $\mathrm{NH}_{\mathrm{x}}$ dry deposition is mainly through $\mathrm{NH}_{3}$ gas $(82 \%)$. Dry deposition of $\mathrm{NO}_{\mathrm{y}}$ is partitioned as $55 \% \mathrm{HNO}_{3}, 22 \% \mathrm{NO}_{2}, 9 \%$ isoprene nitrates, $3.0 \%$ PAN, $2.3 \%$ nitrate aerosol, and $8.7 \%$ other species. The US is a net annual exporter of $2.5 \mathrm{Tg} \mathrm{N}$ as $\mathrm{NO}_{\mathrm{y}}\left(38 \%\right.$ of domestic $\mathrm{NO}_{\mathrm{x}}$ emissions) and $0.60 \mathrm{Tg} \mathrm{N}$ as $\mathrm{NH}_{\mathrm{x}}$ (21\% of domestic $\mathrm{NH}_{3}$ emissions). Domestic anthropogenic emissions contribute respectively $81 \%$ and $71 \%$ of $\mathrm{NO}_{\mathrm{y}}$ and $\mathrm{NH}_{\mathrm{x}}$ deposited over the contiguous US, foreign anthropogenic emissions contribute $6 \%$ and $8 \%$, and natural emissions $13 \%$ and $21 \%$. The contribution from domestic anthropogenic sources to total nitrogen deposition generally exceeds $70 \%$ in the east and populated areas of the west, and is typically $50-70 \%$ in remote areas of the west. $35 \%$ of the land surface in the contiguous US receives nitrogen deposition in excess of $10 \mathrm{~kg} \mathrm{Nha}^{-1} \mathrm{a}^{-1}$. A follow-up study will provide a more detailed source attribution of nitrogen deposition in the US.

Acknowledgements. This work was supported by the Electric Power Research Institute (EPRI). The authors acknowledge the work of many individuals who have made the Midwest RPO, SEARCH, NADP, CAPMoN, CASTNet, EPA-AQS and OMI measurements.

Edited by: R. Harley

\section{References}

Abbatt, J. P. D.: Interaction of $\mathrm{HNO}_{3}$ with water-ice surfaces at temperatures of the free troposphere, Geophys. Res. Lett., 24, 1479$1482,1997$.

Amos, H. M., Jacob, D. J., Holmes, C. D., Fisher, J. A., Wang, Q., Yantosca, R. M., Corbitt, E. S., Galarneau, E., Rutter, A. P., Gustin, M. S., Steffen, A., Schauer, J. J., Graydon, J. A., Louis, V. L. St., Talbot, R. W., Edgerton, E. S., Zhang, Y., and Sunderland, E. M.: Gas-particle partitioning of atmospheric $\mathrm{Hg}(\mathrm{II})$ and its effect on global mercury deposition, Atmos. Chem. Phys., 12, 591-603, doi:10.5194/acp-12-591-2012, 2012.

Aneja, V. P., Chauhan, J. P., and Walker, J. T.: Characterization of atmospheric ammonia emissions from swine waste storage and treatment lagoons, J. Geophys. Res., 105, 11535-11545, 2000.

Asman, W. A. H., Sutton, M. A., and Schjørring, J. K.: Ammonia: emission, atmospheric transport and deposition, New Phytol., 139, 27-48, 1998.

Baughcum, S. L., Tritz, T. G., Henderson, S. C., and Pickett, D. C.: Scheduled Civil Aircraft Emission Inventories for 1992: Database Development and Analysis. NASA Contractor Report 4700, 1996.

Bertram, T. H. and Thornton, J. A.: Toward a general parameterization of $\mathrm{N}_{2} \mathrm{O}_{5}$ reactivity on aqueous particles: the competing effects of particle liquid water, nitrate and chloride, Atmos. Chem. Phys., 9, 8351-8363, doi:10.5194/acp-9-8351-2009, 2009.

Bertram, T. H., Thornton, J. A., Riedel, T. P., Middlebrook, A. M., Bahreini, R., Bates, T. S., Quinn, P. K., and Coffman, D. J.: Direct observations of $\mathrm{N}_{2} \mathrm{O}_{5}$ reactivity on ambient aerosol particles, Geophys. Res. Lett., 36, L19803, doi:10.1029/2009g1040248, 2009.

Bey, I., Jacob, D. J., Yantosca, R. M., Logan, J. A., Field, B. D., Fiore, A. M., Li, Q., Liu, H., Mickley, L. J., and Schultz, M. G.: Global modeling of tropospheric chemistry with assimilated meteorology: Model description and evaluation, J. Geophys. Res., 106, 23073-23096, 2001.

Binkowski, F. S. and Roselle, S. J.: Models-3 Community Multiscale Air Quality (CMAQ) model aerosol component: 1. Model description, J. Geophys. Res., 108, 4183, doi:10.1029/2001JD001409, 2003.

Bobbink, R. B., Hornung, M., and Roelofs, J. G. M.: The effects of air-borne nitrogen pollutants on species diversity in natural and semi-natural European vegetation, J. Ecol., 86, 717-738, 1998.

Boersma, K. F., Eskes, H. J., Dirksen, R. J., van der A, R. J., Veefkind, J. P., Stammes, P., Huijnen, V., Kleipool, Q. L., Sneep, M., Claas, J., Leitão, J., Richter, A., Zhou, Y., and Brunner, D.: An improved tropospheric $\mathrm{NO}_{2}$ column retrieval algorithm for the Ozone Monitoring Instrument, Atmos. Meas. Tech., 4, 19051928, doi:10.5194/amt-4-1905-2011, 2011.

Bouwman, A. F., Lee, D. S., Asman, W. A. H., Dentener, F. J., Van Der Hoek, K. W., and Olivier, J. G. J.: A global high resolution emission inventory for ammonia. Global Biogeochem. Cy., 11, 561-587. 1997.

Bouwman, A. F., van Vuuren, D. P., Derwent, R. G., and Posch, M.: A global analysis of acidification and eutrophication of terrestrial ecosystems, Water Air Soil Poll., 141, 349-382, 2002.

Bowman, W. D., Cleveland, C. C., Halada, Å., Hreško, J., and Baron, J. S.: Negative impact of nitrogen deposition on soil buffering capacity, Nat. Geosci., 1, 767-770, doi:10.1038/ngeo339, 2008. 
Brown, S. S., Dubé, W. P., Fuchs, H., Ryerson, T. B., Wollny, A. G., Brock, C. A., Bahreini, R., Middlebrook, A. M., Neuman, J. A., Atlas, E., Roberts, J. M., Osthoff, H. D., Trainer, M., Fehsenfeld, F. C., and Ravishankara, A. R.: Reactive uptake coefficients for N2O5determined from aircraft measurements during the Second Texas Air Quality Study: Comparison to current model parameterizations, J. Geophys. Res., 114, D00F10, doi:10.1029/2008jd011679, 2009.

Businger, J. A., Wyngaard, J. C., Izumi, Y., and Bradley, E. F.: Fluxprofile relationships in the atmospheric surface layer, J. Atmos. Sci., 28, 181-189, 1971.

Chen, D., Wang, Y. X., McElroy, M. B., He, K., Yantosca, R. M., and Le Sager, P.: Regional CO pollution in China simulated by high-resolution nested-grid GEOS-Chem model, Atmos. Chem. Phys., 11, 3825-3839, doi:10.5194/acp-11-3825-2009, 2009.

Clarke, J. F., Edgerton, E. S., and Martin, B. E.: Dry deposition calculations for the Clean Air Status and Trends Network, Atmos. Environ., 31, 3667-3678, 1997.

Davis, J. M., Bhave, P. V., and Foley, K. M.: Parameterization of $\mathrm{N}_{2} \mathrm{O}_{5}$ reaction probabilities on the surface of particles containing ammonium, sulfate, and nitrate, Atmos. Chem. Phys., 8, 52955311, doi:10.5194/acp-8-5295-2008, 2008.

Dentener, F., Drevet, J., Lamarque, J. F., Bey, I., Eickhout, B., Fiore, A. M., Hauglustaine, D., Horowitz, L. W., Krol, M., Kulshrestha, U. C., Lawrence, M., Galy-Lacaux, C., Rast, S., Shindell, D., Stevenson, D., Van Noije, T., Atherton, C., Bell, N., Bergman, D., Butler, T., Cofala, J., Collins, B., Doherty, R., Ellingsen, K., Galloway, J., Gauss, M., Montanaro, V., Müller, J. F., Pitari, G., Rodriguez, J., Sanderson, M., Solmon, F., Strahan, S., Schultz, M., Sudo, K., Szopa, S., and Wild, O.: Nitrogen and sulfur deposition on regional and global scales: A multimodel evaluation, Global Biogeochem. Cy., 20, GB4003, doi:10.1029/2005GB002672, 2006.

Doskey, P. V., Kotamarthi, V. R., Fukui, Y., Cook, D. R., Breitbeil III, F. W., and Wesely, M. L.: Air-surface exchange of peroxyacetyl nitrate at a grassland site, J. Geophys. Res., 109, D10310, doi:10.1029/2004JD004533, 2004.

Edgerton, E., Saylor, R., Hartsell, B., Jansen, J., and Alanhansen, D.: Ammonia and ammonium measurements from the southeastern United States, Atmos. Environ., 41, 3339-3351, doi:10.1016/j.atmosenv.2006.12.034, 2007.

Ellis, R. A., Murphy, J. G., Markovic, M. Z., VandenBoer, T. C., Makar, P. A., Brook, J., and Mihele, C.: The influence of gasparticle partitioning and surface-atmosphere exchange on ammonia during BAQS-Met, Atmos. Chem. Phys., 11, 133-145, doi:10.5194/acp-11-133-2011, 2011.

Evans, M. J. andJacob, D. J.: Impact of new laboratory studies of N2O5 hydrolysis on global model budgets of tropospheric nitrogen oxides, ozone, and OH, Geophys. Res. Lett., 32, L09813, doi:10.1029/2005g1022469, 2005.

Fisher, J. A., Jacob, D. J., Wang, Q., Bahreini, R., Carouge, C. C., Cubison, M. J., Dibb, J. E., Diehl, T., Jimenez, J. L., Leibensperger, E. M., Lu, Z., Meinders, M. B. J., Pye, H. O. T., Quinn, P. K., Sharma, S., Streets, D. G., van Donkelaar, A., and Yantosca, R. M.: Sources, distribution, and acidity of sulfateammonium aerosol in the Arctic in winter-spring, Atmos. Environ., 45, 7301-7318, doi:10.1016/j.atmosenv.2011.08.030, 2011.

Galloway, J. N., Dentener, F. J., Capone, D. G., Boyer, E. W., Howarth, R. W., Seitzinger, S. P., Asner, G. P., Cleveland, C. C.,
Green, P. A., Holland, E. A., Karl, D. M., Michaels, A. F., Porter, J. H., Townsend, A. R., and Vorosmarty, C. J.: Nitrogen cycles: past, present, and future, Biogeochem., 70, 153-226, 2004.

Geigert, M. A., Nikolaidis, N. P., Miller, D. R., and Heitert, J.: Deposition rates for sulfur and nitrogen to a hardowood forest in northern Connecticut, USA, Atmos. Environ., 28, 1689-1697, 1994.

Gilliland, A. B., Dennis, R. L., Roselle, S. J., and Pierce, T. E.: Seasonal $\mathrm{NH}_{3}$ emission estimates for the eastern United States based on ammonium wet concentrations and an inverse modeling method, J. Geophys. Res., 108, D15, 4477, doi:10.1029/2002jd003063, 2003.

Gilliland, A. B., Wyat Appel, K., Pinder, R. W., and Dennis, R. L.: Seasonal $\mathrm{NH}_{3}$ emissions for the continental United States: Inverse model estimation and evaluation, Atmos. Environ., 40, 4986-4998, 2006.

Guenther, A., Karl, T., Harley, P., Wiedinmyer, C., Palmer, P. I., and Geron, C.: Estimates of global terrestrial isoprene emissions using MEGAN (Model of Emissions of Gases and Aerosols from Nature), Atmos. Chem. Phys., 6, 3181-3210, doi:10.5194/acp-63181-2006, 2006.

Hicks, B.: Dry deposition to forests - On the use of data from clearings, Agr. Forest Meteorol., 136, 214-221, doi:10.1016/j.agrformet.2004.06.013, 2006.

Holland, E. A., Bradswell, B. H., Sulzman, J., and Lamarque, J.-F.: Nitrogen Deposition onto the United States and Western Europe: Synthesis of Observations and Models, Ecol. Appl., 15, 38-57, 2005.

Horii, C. V., William Munger, J., Wofsy, S. C., Zahniser, M., Nelson, D., and Barry McManus, J.: Atmospheric reactive nitrogen concentration and flux budgets at a Northeastern U.S. forest site, Agr. Forest Meteorol., 133, 210-225, 2005.

Horowitz, L. W., Liang, J., Gardner, G., and Jacob, D. J.: Export of reactive nitrogen from North America during summertime: Sensitivity to hydrocarbon chemistry, J. Geophys. Res., 103, 1345113476, 1998.

Hudman, R. C., Jacob, D. J., Turquety, S., Leibensperger, E. M., Murray, L. T., Wu, S., Gilliland, A. B., Avery, M., Bertram, T. H., Brune, W., Cohen, R. C., Dibb, J. E., Flocke, F. M., Fried, A., Holloway, J., Neuman, J. A., Orville, R., Perring, A., Ren, X., Sachse, G. W., Singh, H. B., Swanson, A., and Wooldridge, P. J.: Surface and lightning sources of nitrogen oxides over the United States: Magnitudes, chemical evolution, and outflow, J. Geophys. Res., 112, D12S05, doi:10.1029/2006jd007912, 2007.

Jacob, D. J.: Heterogeneous chemistry and tropospheric ozone, Atmos. Environ., 34, 2131-2159, 2000.

Jacob, D. J., Logan, J. A., Gardner, G. M., Yevich, R. M., Spivakovsky, C. M., Wofsy, S. C., Sillman, S., and Prather, M. J.: Factors Regulating Ozone Over the United States and Its Export to the Global Atmosphere, J. Geophys. Res., 98, 14817-14826, doi:10.1029/98jd01224, 1993.

Kasibhatla, P. S., Levy Ii, H., and Moxim, W. J.: GLobal $\mathrm{NO}_{\mathrm{x}}$, $\mathrm{HNO}_{3}$, PAN, and NOy distrubtions from fossil fuel combustion emissions: A model study, J. Geophys. Res., 98, 7165-7180, 1993.

Kuhns, H., Knipping, E. M., and Vukovich, J. M.: Development of a United States-Mexico emissions inventory for the Big Bend Regional Aerosol and Visibility Observational (BRAVO) Study, J. Air Waste Manage., 55, 677-692, 2005. 
Lamsal, L. N., Martin, R. V., van Donkelaar, A., Celarier, E. A., Bucsela, E. J., Boersma, K. F., Dirksen, R., Luo, C., and Wang, Y.: Indirect validation of tropospheric nitrogen dioxide retrieved from the OMI satellite instrument: Insight into the seasonal variation of nitrogen oxides at northern midlatitudes, J. Geophys. Res., 115, D05302, doi:10.1029/2009jd013351, 2010.

Lerdau, M. T., Munger, J. W., Jacob, D. J.: The $\mathrm{NO}_{2}$ flux conundrum, Science, 289, 2291-2293, 2000.

Li, Q., Jacob, D. J., Munger, J. W., Yantosca, R. M., and Parrish, D. D.: Export of $\mathrm{NO}_{\mathrm{y}}$ from the North American boundary layer: Reconciling aircraft observations and global model budgets, J. Geophys. Res., 109, D02313, doi:10.1029/2003jd004086, 2004.

Liang, J., Horowitz, L. W., Jacob, D. J., Wang, Y., Fiore, A. M., Logan, J. A., Gardner, G. M., and Munger, J. W.: Seasonal budgets of reactive nitrogen species and ozone over the United States, and export fluxes to the global atmosphere, J. Geophys. Res., 103, 13435-13450, 1998.

Liu, H. Y., Jacob, D. J., Bey, I., and Yantosca, R. M.: Constraints from $\mathrm{Pb}-210$ and $\mathrm{Be}-7$ on wet deposition and transport in a global three-dimensional chemical tracer model driven by assimilated meteorological fields, J. Geophys. Res., 106, 1210912128, 2001.

Macintyre, H. L. and Evans, M. J.: Sensitivity of a global model to the uptake of $\mathrm{N}_{2} \mathrm{O}_{5}$ by tropospheric aerosol, Atmos. Chem. Phys., 10, 7409-7414, doi:10.5194/acp-10-7409-2010, 2010.

Mao, J., Jacob, D. J., Evans, M. J., Olson, J. R., Ren, X., Brune, W. H., Clair, J. M. S., Crounse, J. D., Spencer, K. M., Beaver, M. R., Wennberg, P. O., Cubison, M. J., Jimenez, J. L., Fried, A., Weibring, P., Walega, J. G., Hall, S. R., Weinheimer, A. J., Cohen, R. C., Chen, G., Crawford, J. H., McNaughton, C., Clarke, A. D., Jaeglé, L., Fisher, J. A., Yantosca, R. M., Le Sager, P., and Carouge, C.: Chemistry of hydrogen oxide radicals $\left(\mathrm{HO}_{\mathrm{x}}\right)$ in the Arctic troposphere in spring, Atmos. Chem. Phys., 10, 58235838, doi:10.5194/acp-10-5823-2010, 2010.

Mari, C., Jacob, D. J., and Bechtold, P.: Transport and scavenging of soluble gases in a deep convective cloud, J. Geophys. Res., 105, 22255-22267, 2000.

Martin, R. V., Jacob, D. J., Yantosca, R. M., Chin, M., and Ginoux, P.: Global and regional decreases in tropospheric oxidants from photochemical effects of aerosols, J. Geophys. Res., 108, 4097, doi:10.1029/2002JD002622, 2003.

Martin, R. V., Sauvage, B., Folkins, I., Sioris, C. E., Boone, C., Bernath, P., and Ziemke, J.: Space-based constraints on the production of nitric oxide by lightning, J. Geophys. Res., 112, D09309, doi:10.1029/2006jd007831, 2007.

Mentel, T. F., Sohn, M., and Wahner, A.: Nitrate effect in the heterogeneous hydrolysis of dinitrogen pentoxide on aqueous aerosols, Phys. Chem. Chem. Phys., 1, 5451-5457, doi:10.1039/a905338g, 1999.

O’Byrne, G., Martin, R. V., van Donkelaar, A., Joiner, J., and Celarier, E. A.: Surface reflectivity from the Ozone Monitoring Instrument using the Moderate Resolution Imaging Spectroradiometer to eliminate clouds: Effects of snow on ultraviolet and visible trace gas retrievals, J. Geophys. Res., 115, D17305, doi:10.1029/2009JD013079, 2010.

Olivier, J. G. J., Berdowski, J. J. M.: Global emissions sources and sinks, in: The Climate System, edited by: Berdowski, J., Guicherit, R., and Heij, B. J., 33-78, A.A. Balkema Publishers/Swets \& Zeitlinger Publishers, Lisse, The Netherlands, 2001.
Park, R. J., Jacob, D. J., Field, B. D., Yantosca, R. M., and Chin, M.: Natural and transboundary pollution influences on sulfate-nitrate-ammonium aerosols in the United States: Implications for policy, J. Geophys. Res., 109, D15204, doi:10.1029/2003jd004473, 2004.

Pickering, K. E., Wang, Y. S., Tao, W. K., Price, C., and Muller J. F.: Vertical distributions of lightning NOx for use in regional and global chemical transport models. J. Geophys. Res., 103, 3120331216, 1998.

Pinder, R. W., Adams, P. J., Pandis, S. N., and Gilliland, A. B.: Temporally resolved ammonia emission inventories: Current estimates, evaluation tools, and measurement needs, J. Geophys. Res., 111, D16310, doi:10.1029/2005jd006603, 2006.

Price, C. and Rind, D.: A simple lightning parameterization for calculating global lightning distributions, J. Geophys. Res. 97, 9919-9933, 1992.

Reay, D. S., Dentener, F., Smith, P., Grace, J., and Feely, R. A.: Global nitrogen deposition and carbon sinks, Nat. Geosci., 1, 430-437, 2008,

Roberts, J. M., Osthoff, H. D., Brown, S. S., Ravishankara, A. R., Coffman, D., Quinn, P., and Bates, T.: Laboratory studies of products of $\mathrm{N}_{2} \mathrm{O}_{5}$ uptake on Cl-containing substrates, Geophys. Res. Lett., 36, L20808, doi:10.1029/2009g1040448, 2009.

Sanderson, M. G., Dentener, F. J., Fiore, A. M., Cuvelier, C., Keating, T. J., Zuber, A., Atherton, C. S., Bergmann, D. J., Diehl, T., Doherty, R. M., Duncan, B. N., Hess, P., Horowitz, L. W., Jacob, D. J., Jonson, J. E., Kaminski, J. W., Lupu, A., MacKenzie, I. A., Mancini, E., Marmer, E., Park, R., Pitari, G., Prather, M. J., Pringle, K. J., Schroeder, S., Schultz, M. G., Shindell, D. T., Szopa, S., Wild, O., and Wind, P.: A multi-model study of the hemispheric transport and deposition of oxidised nitrogen, Geophys. Res. Lett., 35, L17815, doi:10.1029/2008GL035389, 2008.

Sauvage, B., Martin, R. V., van Donkelaar, A., Liu, X., Chance, K., Jaeglé, L., Palmer, P. I., Wu, S., and Fu, T.-M.: Remote sensed and in situ constraints on processes affecting tropical tropospheric ozone. Atmos. Chem. Phys. 7, 815-838, doi:10.5194/acp-7-815-2007, 2007.

Schindler, D. W., Dillon, P. J., and Schreier, H.: A review of anthropogenic sources of nitrogen and their effects on Canadian aquatic ecosystems, Biogeochemistry, 79, 25-44, doi:10.1007/s10533006-9001-2, 2006.

Sievering, H., Enders, G., Kins, L., Kramm, G., Ruoss, K., Roider, G., Zelger, M., Anderson, L., and Dlugi, R.: Nitric acid, particulate nitrate and ammonium profiles at the Bayerischer Wald: evidence for large deposition rates of total nitrate, Atmos. Environ., 28, 311-315, 1994.

Sievering, H., Kelly, T., McConville, G., Seibold, C., and Turnipseed, A.: Nitric acid dry deposition to conifer forests: Niwot Ridge spruce-fir-pine study. Atmos. Environ., 35, 38513859, 2001.

Smith, S. N., and Mueller, S. F.: Modeling natural emissions in the Community Multiscale Air Quality (CMAQ) Model-I: building an emissions data base, Atmos. Chem. Phys., 10, 4931-4952, 2010 , http://www.atmos-chem-phys.net/10/4931/2010/.

Stevens, C. J., Dise, N. B., Mountford, J. O., and Gowing, D. J.: Impact of nitrogen deposition on the species richness of grasslands, Science, 303, 1876-1879, 2004. 
Sutton, M. A., Burkhardt, J. K., Guerin, D., Nemitz, E., and Fowler, D.: Development of resistance models to describe measurements of bi-directional ammonia surface-atmosphere exchange, Atmos. Environ., 32, 473-480, 1998.

Thornton, J. A., Kercher, J. P., Riedel, T. P., Wagner, N. L., Cozic, J., Holloway, J. S., Dubé, W. P., Wolfe, G. M., Quinn, P. K., Middlebrook, A. M., Alexander, B., and Brown, S. S.: A large atomic chlorine source inferred from mid-continental reactive nitrogen chemistry, Nature, 464, 271-274, doi:10.1038/nature08905, 2010.

Turnipseed, A. A., Huey, L. G., Nemitz, E., Stickel, R., Higgs, J., Tanner, D. J., Slusher, D. L., Sparks, J. P., Flocke, F., and Guenther, A.: Eddy covariance fluxes of peroxyacetyl nitrates (PANs) and $\mathrm{NO}_{\mathrm{y}}$ to a coniferous forest, J. Geophys. Res., 111, D09304, doi:10.1029/2005jd006631, 2006.

US EPA (Environmental Protection Agency): Integrated Science Assessment (ISA) f Oxides of Nitrogen and Sulfur-Ecological Criteria (Final Report). EPA/600/R-08/082F, US Environmental Prot Assessment-RTP Division, Office of Research and Development, Research Triangle Park, NC, USA, available at http: //cfpub.epa.gov/ncea/cfm/recordisplay.cfm?deid=201485, 2008.

van der Werf, G. R., Randerson, J. T., Giglio, L., Collatz, J. G., Kasibhatla, P., and Arellano, A. F.: Interannual variability in global biomass burning emissions from 1997 to 2004, Atmos. Chem. Phys., 6, 3423-3441, doi:10.5194/acp-6-3423-2006, 2006.

van Donkelaar, A., Martin, R. V., Leaitch, W. R., Macdonald, A. M., Walker, T. W., Streets, D. G., Zhang, Q., Dunlea, E. J., Jimenez, J. L., Dibb, J. E., Huey, L. G., Weber, R., and Andreae, M. O.: Analysis of aircraft and satellite measurements from the Intercontinental Chemical Transport Experiment (INTEX-B) to quantify long-range transport of East Asian sulfur to Canada, Atmos. Chem. Phys., 8, 2999-3014, doi:10.5194/acp-8-2999-2008, 2008.

Vestreng, V. and Klein, H.: Emission data reported to UNECE/EMEP. Quality assurance and trend analysis and Presentation of WebDab, MSC-W Status Report 2002, Norwegian Meteorological Institute, Oslo, Norway, 2002.

Vitousek, P. M., Aber, J. D., Howarth, R. W., Likens, G. E., Matson, P. A., Schindler, D. W., Schlesinger, W. H., and Tillman, D. G.: Human alteration of the global nitrogen cycle: Sources and consequences, Ecol. Appl., 7, 737-750. 1997.
Wahner, A., Mentel, T. F., Sohn, M., and Stier, J.: Heterogeneous reaction of $\mathrm{N}_{2} \mathrm{O}_{5}$ on sodium nitrate aerosol, J. Geophys. Res., 103, 31103-31112, 1998.

Wang, J., Hoffmann, A. A., Park, R. J., Jacob, D. J., and Martin, S. T.: Global distribution of solid and aqueous sulfate aerosols: Effect of the hysteresis of particle phase transitions, J. Geophys. Res., 113, D11206, doi:10.1029/2007jd009367, 2008.

Wang, Y. H., Jacob, D. J., and Logan, J. A.: Global simulation of tropospheric $\mathrm{O}_{3}-\mathrm{NO}_{\mathrm{X}}$-hydrocarbon chemistry, J. Geophys. Res., 103, 10713-10725, 1998.

Wang, Y. X., McElroy, M. B., Jacob, D. J., and Yantosca, R. M.: A nested grid formulation for chemical transport over Asia: Applications to CO, J. Geophys. Res., 109, D22307, doi:10.1029/2004jd005237, 2004.

Wesely, M. L.: Parameterization of surface resistances to gaseous dry deposition in regional-scale numerical-models, Atmos. Environ., 23, 1293-1304, 1989.

Wolfe, G. M., J. A. Thornton, R. L. N. Yatavelli, et al., Eddy covariance fluxes of acyl peroxy nitrates (PAN, PPN and MPAN) above a Ponderosa pine forest, Atmos. Chem. Phys., 9, 615-635, doi:10.5194/acp-9-615-2009, 2009.

Yienger, J. J. and Levy II, H.: Empirical model of global soil biogenic $\mathrm{NO}_{\mathrm{x}}$ emissions, J. Geophys. Res., 100, 11447-11464, 1995.

Zhang, L., Jacob, D. J., Downey, N. V., Wood, D. A., Blewitt, D., Carouge, C. C., van Donkelaar, A., Jones, D. B. A., Murray, L. T., and Wang, Y.: Improved estimate of the policy-relevant background ozone in the United States using the GEOS-Chem global model with $1 / 2^{\circ} \times 2 / 3^{\circ}$ horizontal resolution over North America, Atmos. Environ., 45, 6769-6776, doi:10.1016/j.atmosenv.2011.07.054, 2011.

Zhang, Q., Streets, D. G., Carmichael, G. R., He, K. B., Huo, H., Kannari, A., Klimont, Z., Park, I. S., Reddy, S., Fu, J. S., Chen, D., Duan, L., Lei, Y., Wang, L. T., and Yao, Z. L.: Asian emissions in 2006 for the NASA INTEX-B mission, Atmos. Chem. Phys., 9, 5131-5153, doi:10.5194/acp-9-5131-2009, 2009. 